\title{
A hybrid heterogeneous Pythagorean fuzzy group decision modelling for crowdfunding development process pathways of fintech-based clean energy investment projects
}

Yue Meng ${ }^{1}$, Haoyue Wu${ }^{2}$, Wenjing Zhao ${ }^{1}$, Wenkuan Chen $^{2^{*}}$, Hasan Dinçer ${ }^{3}$ and Serhat Yüksel ${ }^{3^{*}}$ (0)

\section{*Correspondence:}

cwk_academic@sina.com;

serhatyuksel@medipol.edu.tr

${ }^{2}$ College of Management,

Sichuan Agricultural

University, Chengdu 611830,

China

${ }^{3}$ School of Business,

Istanbul Medipol University,

Kavacık Mah. Ekinciler Cad.

No: 19, Kavacık Kavşağı,

34810 Beykoz, Istanbul,

Turkey

Full list of author information is available at the end of the article

\begin{abstract}
This study aims to evaluate the crowdfunding alternatives regarding new service development process pathways of clean energy investment projects. In this framework, a new model has been generated by considering the consensus-based group decisionmaking with incomplete preferences, Pythagorean fuzzy decision-making trial and evaluation laboratory (DEMATEL) and technique for order preference by similarity to ideal solution (TOPSIS). Moreover, a comparative evaluation has been performed with Vise Kriterijumska Optimizacija I. Kompromisno Resenje methodology and sensitivity analysis has been made by considering 4 different cases. The main contribution is to identify appropriate crowdfunding-based funding alternatives for the improvement of the clean energy investments with a novel MCDM model. By considering the iteration technique and consensus-based analysis, the missing parts in the evaluations can be completed and opposite opinion problems can be reduced. Furthermore, with the help of hybrid MCDM model by combining DEMATEL and TOPSIS, more objective results can be reached. It is concluded that the analysis results are coherent and reliable. The findings indicate that the full launch is the most significant criterion for equity and debt-based crowdfunding alternatives. On the other side, the analysis has the highest weight for reward and donation-based alternatives whereas design is the most essential item regarding the royalty-based alternative. Additionally, it is also defined that equity-based crowdfunding alternative is the most significant for the service development process of clean energy investment projects. In this way, it will be possible to provide a continuous resource for clean energy investment projects. On the other hand, by providing financing with equity, there will be no fixed financing cost for clean energy investors. If these investors make a profit, they distribute dividends with the decision of their authorized bodies.
\end{abstract}

Keywords: Crowdfunding, Project financing, Clean energy investments, New service development, PERT, Group decision making, Pythagorean fuzzy sets, DEMATEL, TOPSIS, VIKOR 


\section{Introduction}

Environmental pollution threatens all living things; increasing environmental pollution is a significant problem worldwide. If pollution is not controlled, bigger problems are probable for the future. Thus, many countries are working towards reducing the environmental pollution problem (Bashir et al. 2020). Energy consumption is a major issue causing the most environmental pollution because the use of fossil fuels releases dangerous amounts of carbon gases into the atmosphere. Thus, while some countries are closing down thermal power plants, others are using fossil fuels with carbon capture technologies (Albino et al. 2014).

Due to these considerations, the requirement for clean energy has increased significantly. Clean energy does not cause environmental pollution while generating electricity (Lowitzsch et al. 2020). These types of natural resources of energy include solar, wind, and geothermal, and the benefits of clean energy projects are numerous. First, as it does not cause environmental pollution, the number of individuals suffering from illness due to pollution is decreasing. Furthermore, healthy individuals mean a reduction in the loss of the labor force and an increase in the quality of life (Mangla et al. 2020). Additionally, countries can produce energy for themselves due to clean energy projects, which may result in a decrease in the amount of imports countries pay for energy supply and a reduction in the current account deficit problem.

Hence, clean energy investments are vital for economic development. Therefore, these projects should be increased with effective energy policies. There are some negative aspects about clean energy investments, such as having high initial costs (Shankar et al. 2020) and being long-term projects, which decrease the motivation of some investors. Therefore, to encourage clean energy projects and gain effective funds, these issues must first be resolved (Carter et al. 2020).

Crowdfunding has increased in popularity in recent years. In this system, small funds are obtained from many individuals (Langley et al. 2020). A major advantage is that many investors can be reached quickly, and there are different crowdfunding applications (Roma et al. 2017). An equity-based crowdfunding system explains that private company securities are sold to a group. Debt-based crowdfunding means that investors purchase the debt securities of the business (Block et al. 2020). Reward-based crowdfunding is where individuals donate to a project in anticipation of receiving a non-financial reward, such as a good or service, at a later stage (Vrontis et al. 2020). Royalty-based crowdfunding presents a percentage of the income from the project. In donation-based crowdfunding, many participants donate small amounts through the system.

This study aims to determine the appropriate crowdfunding alternatives with respect to new service development process pathways of clean energy investment projects using a four-stage novel model. First, the missing values of the relation matrixes are completed by considering the iteration technique. Second, the consensus-based fuzzy preferences for the criteria of the crowdfunding alternatives are defined. Third, the service development process of clean energy investment projects by the crowdfunding alternatives is evaluated with the Pythagorean fuzzy decision-making trial and evaluation laboratory (DEMATEL) approach. Fourth, the service development paths of clean energy investment projects by the crowdfunding alternatives are ranked. To reach this objective, the Pythagorean fuzzy technique for order preference by similarity to ideal solution 
(TOPSIS) methodology is considered. In addition, a comparative evaluation is performed with Vise Kriterijumska Optimizacija I. Kompromisno Resenje (VIKOR) methodology, and sensitivity analysis is made by considering four cases.

The main contribution of this study is to present appropriate crowdfunding-based funding alternatives for the improvement of the clean energy investments with a novel multi-criteria decision-making (MCDM) model by considering the group decisionmaking with consensus and Pythagorean fuzzy set. The proposed model includes novelties. With the help of the iteration technique, the missing parts in the evaluations can be completed. A problem in the decision-making analysis is that experts may not have opinions about some criteria (Zhang et al. 2016a, b) which negatively influences process effectiveness (Liu et al. 2019). Therefore, the iteration technique contributes to solving this problem (Chen et al. 2014). Additionally, experts may have different opinions about some criteria (Wu and Chiclana 2014), which reduces the effectiveness of the decision-making process (Dong et al. 2018). In this study, consensus-based group decision-making methodology is considered to minimize this problem through the feedback mechanism (Labella et al. 2018; Lin et al. 2020; Li et al. 2021).

Additionally, this proposed model uses a hybrid methodology, in which different MCDM techniques are considered for both calculating the weights and ranking the alternatives (Wang et al. 2020), thereby producing more objective results (Zhou et al. 2020; Qiu et al. 2020). Furthermore, this proposed model considers the DEMATEL approach to weigh the factors. The main advantage of this methodology over similar ones is that an impact-relation map can be constructed (Yuan et al. 2020), and the causality analysis between the items can be performed (Delen et al. 2020; Xie et al. 2020). As the TOPSIS methodology considers the distances to both negative and positive ideal solutions (Rani et al. 2020), better results can be reached (Dhiman and Deb 2020; Ziemba et al. 2020). Finally, the analysis is performed by considering the Pythagorean fuzzy sets. These sets include membership, non-membership, and hesitancy parameters (Fei and Deng 2020), which provide more reliable evaluations (Akram et al. 2020a, b; Ma et al. 2020).

The remainder of the paper is as follows. Section 2 provides the literature review by focusing on service development for clean energy investments and crowdfunding alternatives. Section 3 includes describes the consensus-based group decision-making, Pythagorean fuzzy sets, DEMATEL, TOPSIS, and VIKOR approaches. Additionally, the details of the proposed model are provided. Section 4 presents the results and analysis. Section 5 offers the discussion and conclusion.

\section{Literature review}

This section reviews research regarding new service development for clean energy investments and crowdfunding alternatives. The final part discusses the results of the literature review.

\section{New service development for clean energy investments}

Many researchers have stated that the development of new products and services for clean energy investments must closely consider financial issues. As clean energy suffers from high costs and as they are long-term projects, uncertainties are high for investors (Cloke et al. 2017). Therefore, while developing new products for clean energy 
investments, a detailed financial analysis is required (Mirzania et al. 2019). Otherwise, failure to make an effective cost-benefit analysis may damage the project (Lam and Law 2018). Wang et al. (2019) tried to identify the optimal clean energy investment alternatives and, through a comprehensive literature evaluation, identified six criteria that consider both financial and non-financial issues. They highlighted that, while generating new products for clean energy projects, financial aspects should be the main consideration. Moreover, they found that energy from solar and wind is the most profitable clean energy investment alternatives. Yüksel et al. (2019) focused on the key points in international energy trade through considered six criteria. Similarly, they determined that cost-effectiveness should the main consideration for the effectiveness of new products for clean energy investments.

The company's technological competence is a factor affecting new product development performance for clean energy projects. Clean energy investment projects are comprehensive processes that require consideration of multiple factors simultaneously to develop new products (Ratner and Nizhegorodtsev 2017). Companies without technological competence have difficulties developing effective products that serve multiple aspects (Hicks and Ison 2018), which negatively affects these projects (Terrapon-Pfaff et al. 2014). Lacerda and Bergh (2020) evaluated the effectiveness of renewable energy investments through a survey analysis conducted with 508 valid responses. They underlined the significance of technological innovation for the success of the new services in renewable energy investments. Dinçer et al. (2019) analyzed the performance results of the European policies in energy investment by conducting an evaluation that considered quality function deployment methodology. They determined that clean energy companies should have sufficient technical requirements for the success of the new product generation process.

Organizational effectiveness is a key factor for the performance improvement of new services or clean energy projects (Martinez and Komendantova 2020). Hence, communications between the departments should be high-quality (Maqbool 2018), and companies should employ qualified individuals to design clean energy products more effectively (Shi et al. 2016). Cheng et al. (2020) evaluated new service development projects for clean energy investments by examining PERT-based critical paths for these projects. As companies tend to focus on the idea generation process for success in these projects, organizational effectiveness is crucial. Cheng et al. (2020) determined that investors should focus on the generation of new products for solar energy projects. Similarly, Yang et al. (2016) focused on clean energy goals of China. They identified that the harmonious working environment between departments within the company is critical in increasing clean energy investments.

Moreover, researchers have emphasized that customer expectations are vitally important in this process. As there is considerable competition in the clean energy market (Dimić et al. 2018), success in this challenging environment means that clean energy investors must clearly understand customer expectations (Li et al. 2020). Otherwise, there is a risk that new clean energy products introduced in the market will not be preferred by customers (Seetharaman et al. 2016). This will endanger the sustainable performance of clean energy companies in the market. Domigall et al. (2014) focused on the new service development process for clean energy generation, conducting a 
choice-based conjoint analysis with 107 respondents. They identified that companies should satisfy customer needs for success and that new services should be generated based on customer expectations. Additionally, Cocca and Ganz (2015) defined the key requirements regarding the development of green services and underlined the importance of meeting customer requirements for the success of the clean energy investment projects.

\section{Crowdfunding alternatives}

Crowdfunding alternatives have gained popularity in recent years. Many researchers focused on the advantages of equity crowdfunding. Ahlers et al. (2015) stated that crowdfunding provides the opportunity to minimize the risks because companies do not have to pay investors when the company has a loss. Vismara (2016), Vulkan et al. (2016), and Mochkabadi and Volkmann (2020) underlined the importance of this situation in their studies. Additionally, Lukkarinen et al. (2016), Walthoff-Borm et al. (2018), and Hornuf and Neuenkirch (2017) claimed that, with the help of equity crowdfunding, it is easier to build a strong and sustainable relationship with customers. However, some researchers underlined the disadvantages of crowdfunding. Di Pietro et al. (2020) and Hornuf and Schwienbacher (2017) stated that equity crowdfunding may not be appropriate for all industries, especially when the cost of the projects can be more than expected.

Previous studies have examined the alternative of debt crowdfunding. Rossi and Vismara (2018), Gutiérrez-Urtiaga and Sáez-Lacave (2018), and Hörisch (2019) identified that, owing to the debts crowdfunding, the companies can pay a fixed amount of money to the counterparty, which helps manage costs. Cash management can be easier, as companies know about future payouts (Montgomery et al. 2018; Hörisch and Tenner 2020). Additionally, types of crowdfunding have been discussed, such as reward-based crowdfunding (Frydrych et al. 2014; Kraus et al. 2016), royalty-based crowdfunding (Petruzzelli et al. 2019; Lu et al. 2018), and donation-based crowdfunding (Zhang et al. 2020; Salido-Andres et al. 2020). However, it is difficult to continuously fund companies in this way, which is the main disadvantage.

\section{Literature review results}

The literature review demonstrates that interest in clean energy investments has increased significantly, and competition in the sector increases in parallel. Therefore, clean energy investors should give serious importance to developing new products and services. One of the biggest disadvantages of these investments is that the initial cost is quite high. Hence, financing of these investments is of vital importance. This literature review examined different crowdfunding alternatives and compared and explained the positive and negative aspects of these methods. We noted that that there are a limited number of studies focusing on crowdfunding alternatives for clean energy investments. Furthermore, the existing models in the literature for this subject were analyzed. In a significant part of the studies, econometric models, such as regression and cointegration were considered (Hosseini et al. 2019; Huang et al. 2019; Han et al. 2020; Jumin et al. 2021). However, the biggest weakness of these models is that only numerical values are considered in the evaluation process. Therefore, there is a need for research on 
this subject that considers both numerical and nonnumerical indicators. Therefore, this study generates a new model by considering consensus-based group decision-making methodology, Pythagorean fuzzy sets, DEMATEL, and TOPSIS approaches. Hence, with the help of these approaches, both numerical and non-numerical factors are examined.

\section{Methodology}

This section explains the consensus-based group decision-making, Pythagorean fuzzy sets, DEMATEL, TOPSIS, and VIKOR approaches. In addition, the details of the proposed model are presented.

\section{Heterogeneous group decision making}

In the decision-making process, experts give opinions about the factors, and different evaluations by these experts lead to the problem of effectiveness in the process. Consensus-based group decision-making methodology aims to solve this problem (Wu and Chiclana 2014). The fuzzy preference relation (P) indicates the degrees of criteria by a membership function $\mu_{p}: X \times X \rightarrow[0,1]$. Equation (1) presents these details.

$$
P=\left(P_{i k}\right) \text { and } P_{i k}=\mu_{p}\left(x_{i}, x_{k}\right)(\forall i, k \in\{1, \ldots, n\})
$$

Conversely, Eq. (2) demonstrates the corresponding fuzzy preferences (CP), which show the consistency levels of the criteria (Dong et al. 2018).

$$
C P_{i k}=\frac{\sum_{j=1 ; i \neq k \neq j}^{n}\left(C P_{i k}\right)^{j 1}+\cdots+\left(C P_{i k}\right)^{j(n-1)}}{(n-1) *(n-2)}
$$

The consistency level (CL) can be calculated for each pair of criteria as in Eqs. (3) and (4).

$$
\begin{aligned}
C L_{i k} & =1-\left(\frac{2 *\left|C P_{i k}-P_{i k}\right|}{(n-1)}\right) \\
C L_{i} & =\frac{\sum_{k=1 ; i \neq k}^{n}\left(C L_{i k}+C L_{k i}\right)}{2(n-1)} .
\end{aligned}
$$

The global consistency level (GCL) is computed by Eq. (5).

$$
G C L=\frac{\sum_{i=1}^{n} C L_{i}}{n} .
$$

In the next step, the similarity matrices (SM) are defined with the help of Eqs. (6) and (7).

$$
\begin{aligned}
& S M_{i k}^{h l}=1-\left|P_{i k}^{h}-P_{i k}^{l}\right| \\
& S M_{i k}=\phi\left(S M_{i k}^{h l}\right)
\end{aligned}
$$


where $\phi$ demonstrates the aggregation function, and $e_{h}$ and $e_{l}$ give information about the pairs of experts, $(h<l), \forall h, l=1, \ldots, m$. Global consensus degrees (CR) can be identified as in Eq. (8) (Labella et al. 2018).

$$
C R=\frac{\sum_{i=1}^{n} \frac{\sum_{k=1 ; k \neq i}^{n}\left(S M_{i k}+S M_{k i}\right)}{2(n-1)}}{n}
$$

Moreover, Eq. (9) indicates the consensual degrees, where $\delta$. is the control parameter of consistency and consensus degrees. This value is accepted as 0.75 in this study.

$$
Z_{i k}^{h}=(1-\delta) * C L_{i k}^{h}+\delta *\left(\frac{\sum_{l=h+1}^{n} S M_{i k}^{h l}+\sum_{l=1}^{h-1} S M_{i k}^{l h}}{n-1}\right)
$$

The collective fuzzy preference relations $\left(P_{i k}^{c}\right)$ are employed by considering Eqs. (10)(12), where $\sigma$ represents a permutation of $\{1, \ldots, m\}, Z_{i k}^{\sigma(h)} \geq Z_{i k}^{\sigma(h+1)}, \forall h=1, \ldots, m-1$, and $Z_{i k}^{\sigma(h)}, P_{\sigma(i)}$ presents two-tuple with $\left\langle Z_{i k}^{\sigma(h)}\right\rangle$ in $\left\{\left\langle Z_{i k}^{1}\right\rangle, \ldots,\left\langle Z_{i k}^{m}\right\rangle\right\}$.

$$
\begin{aligned}
& P_{i k}^{c}=\Phi w\left(Z_{i k}^{1}, P_{i k}^{1}, \ldots, Z_{i k}^{m}, P_{i k}^{m}\right)=\sum_{h=1}^{m} w_{h} * P_{i k}^{\sigma(h)} \\
& \left.w_{h}=Q(h / n)-Q(h-1) / n\right) \\
& (r)= \begin{cases}0 & \text { if } r<a \\
\frac{r-a}{b-a} & \text { if } a \leq r \leq b \\
1 & \text { if } r>a\end{cases}
\end{aligned}
$$

The proximity levels $\left(P P_{i k}^{h}\right)$ and the relation between criteria $P r^{h}$ are defined by Eqs. (13) and (14), respectively (Dong et al. 2018).

$$
\begin{aligned}
& P P_{i k}^{h}=1-\left|P_{i k}^{h}-P_{i k}^{c}\right| \\
& \operatorname{Pr}^{h}=\frac{\sum_{i=1}^{n} \frac{\sum_{k=1 ; k \neq i}^{n}\left(P P_{i k}^{h}+P P_{k i}^{h}\right)}{2(n-1)}}{n}
\end{aligned}
$$

Next, the consensus control level (CCL) is calculated using Eq. (15) and measures the consensus among the decision-makers.

$$
C C L=(1-\delta) * G C L+\delta * C R
$$

The final consensus result is compared with a threshold value $\gamma \in[0.1]$, which is selected as 0.85 , and the feedback mechanism is applied to obtain the revised values. This process is repeated until the value of CCL is higher than the threshold. The values of EXPCH, ALT, and APS are considered as in Eqs. (16), (17), and (18), respectively (Wu and Chiclana 2014).

$$
E X P C H=\left\{h \mid(1-\delta) * C L^{h}+\delta * \operatorname{Pr}^{h}<\gamma\right\}
$$




$$
\begin{aligned}
& A L T=\left\{(h, i) \mid e_{h} \in E X P C H \wedge(1-\delta) * C L_{i}^{h}+\delta * \frac{\sum_{k=1 ; k \neq i}^{n}\left(P P_{i k}^{h}+P P_{k i}^{h}\right)}{2(n-1)}<\gamma\right\} \\
& A P S=\left\{(h, i, k) \mid(h, i) \in A L T \wedge(1-\delta) * C L_{i k}^{h}+\delta * P P_{i k}^{h}<\gamma\right\}
\end{aligned}
$$

$S=\left\{S_{0}, S_{1}, \ldots, S_{g-1}, S_{g}\right\}$ explains the linguistic term set, and $g$ represents the number of the linguistic preferences. When the decision-making process lacks evaluation, it is called heterogeneous decision-making (Zhang et al. 2016a, b), because the decision-makers may not have information about some criteria or some information will be missing (Liu et al. 2019). Hence, incomplete preferences can be considered to complete these missing parts. The estimation of linguistic preference $e p_{i k}(i \neq k)$ can be made using Eqs. (19)-(22) (Chen et al. 2014).

$$
\begin{aligned}
& \left(e p_{i k}\right)^{j 1}=\Delta\left(\Delta^{-1}\left(p_{i j}\right)+\Delta^{-1}\left(p_{j k}\right)-\Delta^{-1}\left(S_{g / 2}\right)\right) \\
& \left(e p_{i k}\right)^{j 2}=\Delta\left(\Delta^{-1}\left(p_{j k}\right)-\Delta^{-1}\left(p_{j i}\right)+\Delta^{-1}\left(S_{g / 2}\right)\right) \\
& \left(e p_{i k}\right)^{j 3}=\Delta\left(\Delta^{-1}\left(p_{i j}\right)+\Delta^{-1}\left(p_{k j}\right)-\Delta^{-1}\left(S_{g / 2}\right)\right) \\
& e p_{i k}=\Delta\left(\frac{1}{3}\left(\Delta^{-1}\left(e p_{i k}^{1}\right)+\Delta^{-1}\left(e p_{i k}^{2}\right)+\Delta^{-1}\left(e p_{i k}^{3}\right)\right)\right)
\end{aligned}
$$

\section{Pythagorean fuzzy sets}

Pythagorean fuzzy sets $(\mathrm{P})$ indicate a new class of non-standard fuzzy membership grades over a universal set $\vartheta$. Equation (23) shows the details of this process (Ma et al. 2020).

$$
P=\left\{\left\langle\vartheta, \mu_{P}(\vartheta), n_{P}(\vartheta)\right\rangle / \vartheta U \in\right\}
$$

where $\mu_{P}$ and $n_{P}: U \rightarrow[0,1]$ represent the membership and non-membership, respectively, of the element $\vartheta \in U$. Additionally, the condition in Eq. (24) should be satisfied (Akram et al. 2020a, b).

$$
\left(\mu_{P}(\vartheta)\right)^{2}+\left(n_{P}(\vartheta)\right)^{2} \leq 1
$$

Then, Eq. (25) indicates the details of the degree of indeterminacy.

$$
\pi_{P}(\vartheta)=\sqrt{1-\left(\mu_{P}(\vartheta)\right)^{2}-\left(n_{P}(\vartheta)\right)^{2}}
$$

Equations (26)-(30) explain the essential operations of Pythagorean fuzzy sets (Fei and Deng 2020).

$$
P_{1}=\left\{\left\langle\vartheta, P_{1}\left(\mu_{P_{1}}(\vartheta), n_{P_{1}}(\vartheta)\right)\right\rangle / \vartheta \in U\right\} \text { and } P_{2}=\left\{\left\langle\vartheta, P_{2}\left(\mu_{P_{2}}(\vartheta), n_{P_{2}}(\vartheta)\right)\right\rangle / \vartheta \in U\right\}
$$




$$
\begin{aligned}
& P_{1} \oplus P_{2}=P\left(\sqrt{\mu_{P_{1}}^{1}+\mu_{P_{2}}^{2}-\mu_{P_{1}}^{1} \mu_{2}^{2}, n_{P_{1}} n_{P_{1}}}\right) \\
& P_{1} \otimes P_{2}=P\left(\mu_{P_{1}} \mu_{P_{2}}, \sqrt{n_{P_{1}}^{2}+n_{P_{2}}^{2}-n_{P_{1}}^{2} n_{P_{2}}^{2}}\right) \\
& \lambda P=P\left(\sqrt{1-\left(1-\mu_{p}^{2}\right)^{\lambda}},\left(n_{p}\right)^{\lambda}\right), \quad \lambda>0 \\
& P^{\lambda}=P\left(\left(\mu_{p}\right)^{\lambda}, \sqrt{1-\left(1-n_{p}^{2}\right)^{\lambda}}\right), \quad \lambda>0
\end{aligned}
$$

Figure 1 illustrates the details of the relationship between intuitionistic (IFS) and Pythagorean fuzzy sets (PFS) (Akram et al. 2020a, b).

The defuzzied values are computed with the help of the score function as described in Eq. (31).

$$
S(\vartheta)=\left|\left(\mu_{P}(\vartheta)\right)^{2}-\left(n_{P}(\vartheta)\right)^{2}\right|
$$

\section{DEMATEL}

DEMATEL methodology aims to find the significant weights of factors, and an impact relation map can be created. This provides the opportunity to evaluate the causal relationship of the items. In the first step, the decision-makers make evaluations, which are converted into linguistic scales. Then, the direct relation matrix (A) is generated, as in Eq. (32), by considering the average values of these evaluations (Yuan et al. 2020).

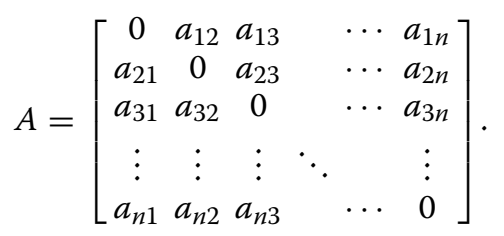

Equations (32) and (33) are used to normalize this matrix.

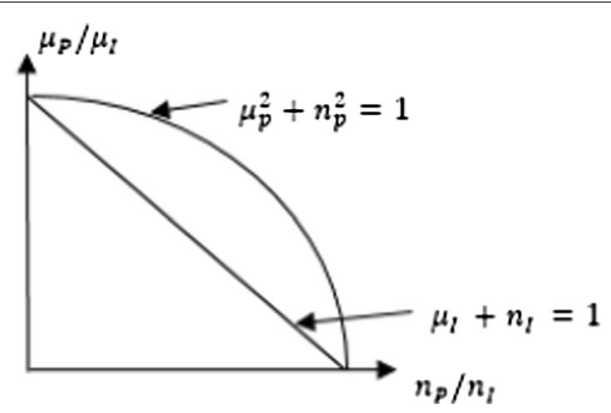

Fig. 1 Membership and non-membership degrees of IFS and PFS 


$$
\begin{aligned}
& B=\frac{A}{\max _{1 \leq i \leq n} \sum_{j=1}^{n} a_{i j}} \\
& 0 \leq b_{i j} \leq 1
\end{aligned}
$$

The total relation matrix $(C)$ is developed by using Eq. (35), where $I$ represents the identity matrix (Delen et al. 2020).

$$
C=B(I-B)^{-1}
$$

Furthermore, the sums of rows and columns (D and E) are computed using Eqs. (35) and (36) (Xie et al. 2020).

$$
\begin{aligned}
& D=\left[\sum_{j=1}^{n} e_{i j}\right]_{n x 1} \\
& E=\left[\sum_{i=1}^{n} e_{i j}\right]_{1 x n}
\end{aligned}
$$

The values of $\mathrm{D}+\mathrm{E}$ are used to find the importance weights of the items. Additionally, the cause-and-effect relationship is computed with the values of D-E. For this purpose, a threshold value $(\alpha)$ is considered as in Eq. (38).

$$
\alpha=\frac{\sum_{i=1}^{n} \sum_{j=1}^{n}\left[e_{i j}\right]}{N}
$$

\section{TOPSIS}

TOPSIS is used to rank the alternatives according to performance. The maximized distance from the negative ideal solutions and the minimized distance from the positive ideal solutions are considered. First, the values are normalized as in Eq. (39) (Ziemba et al. 2020).

$$
r_{i j}=\frac{X_{i j}}{\sqrt{\sum_{i=1}^{m} X_{i j}^{2}}} \quad \mathrm{i}=1,2,3, \ldots \mathrm{m} \quad \text { and } \quad \mathrm{j}=1,2,3, \ldots \mathrm{n}
$$

Additionally, these values are weighted as in Eq. (40), where $w$ represents the weighted factor.

$$
v_{i j}=w_{i j} \times r_{i j} \quad \text { where } \quad \mathrm{i}=1,2, \ldots, \mathrm{m} \quad \text { and } \quad \mathrm{j}=1,2, \ldots, \mathrm{n}
$$

Next, the positive $\left(A^{+}\right)$and negative $\left(A^{-}\right)$ideal solutions are defined using Eqs. (41) and (42) (Dhiman and Deb 2020).

$$
\begin{aligned}
& A^{+}=\left\{v_{1 j}, v_{2 j}, \ldots, v_{m j}\right\}=\left\{\max v_{1 j} \text { for } \forall j \in n\right\} \\
& A^{-}=\left\{v_{1 j}, v_{2 j}, \ldots, v_{m j}\right\}=\left\{\min v_{1 j} \text { for } \forall j \in n\right\}
\end{aligned}
$$


Then, the distances to the best $\left(D_{i}^{+}\right)$and the worst alternative $\left(D_{i}^{-}\right)$are calculated using Eqs. (43) and (44).

$$
\begin{aligned}
& D_{i}^{+}=\sqrt{\sum_{j=1}^{n}\left(v_{i j}-A_{j}^{+}\right)^{2}} \\
& D_{i}^{-}=\sqrt{\sum_{j=1}^{n}\left(v_{i j}-A_{j}^{-}\right)^{2}}
\end{aligned}
$$

Finally, the relative closeness to the ideal solution $\left(\mathrm{RC}_{\mathrm{i}}\right)$ is computed with Eq. (45) (Rani et al. 2020).

$$
R C_{i}=\frac{D_{i}^{-}}{D_{i}^{+}+D_{i}^{-}} \text {for } \mathrm{i}=1,2, \ldots \mathrm{m} \text { and } 0 \leq R C_{i} \leq 1
$$

\section{VIKOR}

VIKOR aims to rank various alternatives according to performance. First, Eq. (46) computes fuzzy best and worst values $\left(\tilde{f}_{j}^{*}, \tilde{f}_{j}^{-}\right)$(Salimi et al. 2020)

$$
\tilde{f}_{J}^{*}=\max _{i} \tilde{x}_{i j} \text {, and } \tilde{f}_{j}^{-}=\min _{i} \tilde{x}_{i j}
$$

Then, Eqs. (47) and (48) are used to calculate the mean group utility $\left(\tilde{S}_{i}\right)$ and maximal regret $\left(\tilde{R}_{i}\right)$ (Rathore et al. 2020).

$$
\begin{gathered}
\tilde{\boldsymbol{S}}_{i}=\sum_{i=1}^{n} \tilde{\boldsymbol{w}}_{j} \frac{\left(\left|\tilde{f}_{j}^{*}-\tilde{\boldsymbol{x}}_{i j}\right|\right)}{\left(\left|\tilde{f}_{j}^{*}-\tilde{\boldsymbol{f}}_{j}^{-}\right|\right)} \\
\tilde{\boldsymbol{R}}_{\boldsymbol{i}}=\max _{j}\left[\tilde{\boldsymbol{w}}_{j} \frac{\left(\left|\tilde{f}_{j}^{*}-\tilde{\boldsymbol{x}}_{i j}\right|\right)}{\left(\left|\tilde{f}_{j}^{*}-\tilde{\boldsymbol{f}}_{j}^{-}\right|\right)}\right]
\end{gathered}
$$

where $w$ represents the fuzzy weights. Next, the value of $\tilde{Q}_{i}$ is computed by Eq. (49) (Akram et al. 2021a, b).

$$
\tilde{Q}_{i}=\boldsymbol{v}\left(\tilde{S}_{i}-\tilde{S}^{*}\right) /\left(\tilde{S}^{-}-\tilde{S}^{*}\right)+(1-\boldsymbol{v})\left(\tilde{\boldsymbol{R}}_{\boldsymbol{i}}-\tilde{\boldsymbol{R}}^{*}\right) /\left(\tilde{\boldsymbol{R}}^{-}-\tilde{\boldsymbol{R}}^{*}\right)
$$

where $v$ denotes the weight of the maximum group utility and $1-v$ is the weight of the individual regret. Finally, the values of S, R, Q are identified. Two different conditions are evaluated to control the consistency of the results. The first condition is highlighted in Eq. (50) (Sharaf 2020).

$$
Q\left(A^{(2)}\right)-Q\left(A^{(1)}\right) \geq \frac{1}{(j-1)}
$$


The acceptable stability in the decision-making process is examined in the second condition. The combination of the alternatives $A^{(1)}$ and $A^{(2)}$ is used if the second condition is not met. However, the alternatives $A^{(1)}, A^{(2)} \ldots, A^{(M)}$ are considered when the first condition is not satisfied (Akram et al. 2021a, b).

\section{Proposed model}

This study examines crowdfunding alternatives regarding new service development process pathways of clean energy investment projects. For this purpose, a novel 4-phase model has been created. Figure 2 provides the details of this model.

The details of the phases and steps are demonstrated below.

Phase 1: Completing the Missing Values of the Relation Matrices.

Step 1: Factors are identified to evaluate the service development process and the crowdfunding alternatives for the clean energy investment projects.

Step 2: Linguistic evaluations are obtained from the four different experts.

Step 3: Incomplete values are calculated for the generation of the full relation matrix.

Phase 2: Determining the Consensus-based Fuzzy Preferences for the Criteria of the Crowdfunding Alternatives.

Step 1: Corresponding fuzzy preference relations are generated.

Step 2: The consistency levels are calculated.

Step 3: Similarity matrix is generated.

Step 4: The consensual degrees are calculated.

Step 5: The proximity values are identified.

Step 6: The feedback mechanism is implemented to check the consensus control levels.

Phase 3: Evaluating the Service Development Process of Clean Energy Investment Projects by the Crowdfunding Alternatives with Pythagorean Fuzzy Sets.

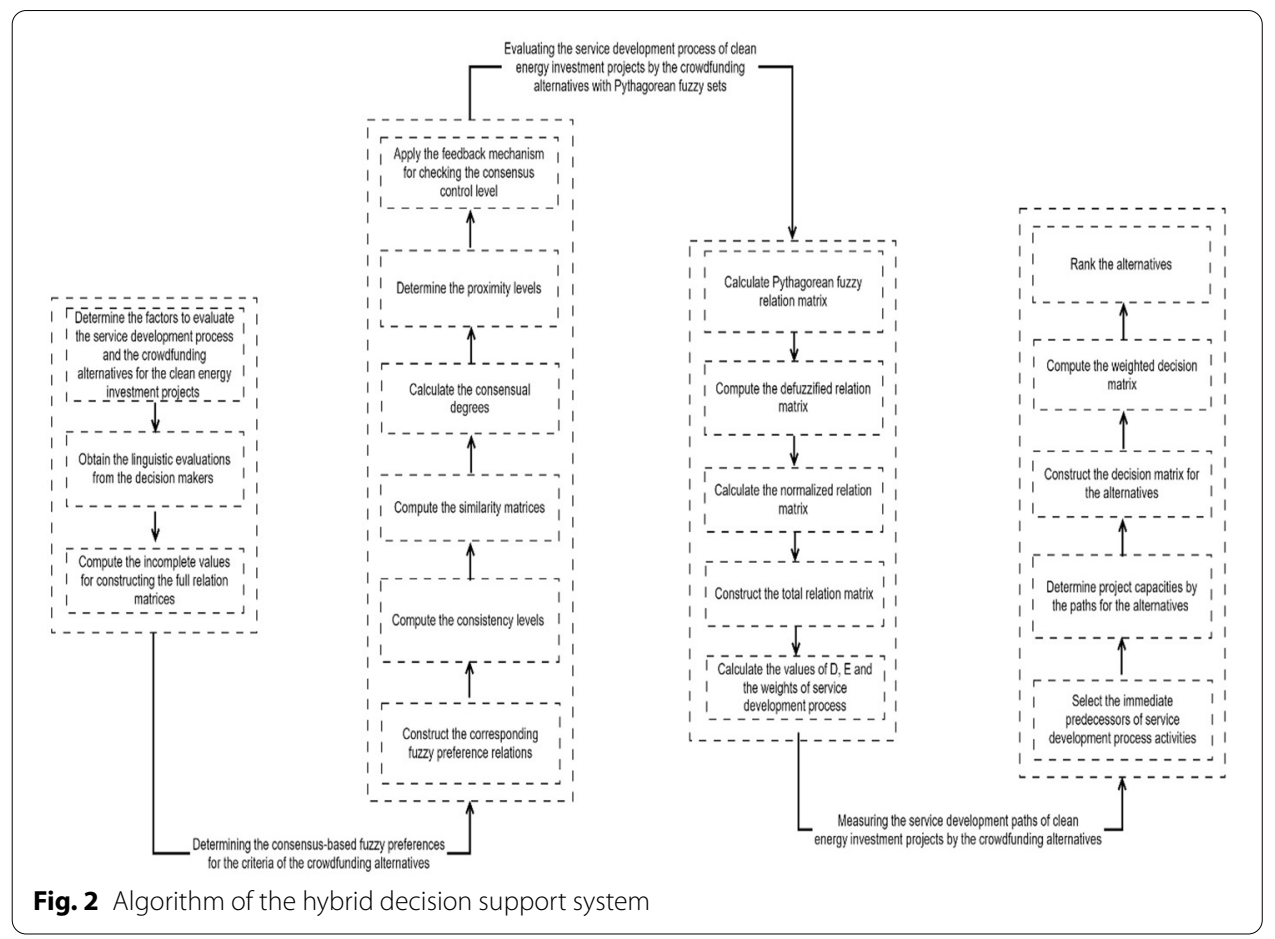


Step 1: Pythagorean fuzzy relation matrix is created.

Step 2: The defuzzified relation matrix is calculated.

Step 3: The normalized relation matrix is generated.

Step 4: The total relation matrix is created.

Step 5: The weights of the service development process are identified.

Phase 4: Measuring the Service Development Paths of Clean Energy Investment Projects by the Crowdfunding Alternatives.

Step 1: Immediate predecessors of the service development activities are defined.

Step 2: The project capacities by the paths are defined for the alternatives.

Step 3: The decision matrix is constructed for the alternatives.

Step 4: The weighted decision matrix is created.

Step 5: The alternatives are ranked. Additionally, a comparative evaluation has been performed with VIKOR methodology and sensitivity analysis has been made by considering 4 different cases.

There are novelties of this proposed model. One of the biggest problems in the decision-making evaluation is that experts may not have opinions about some criteria (Liu et al. 2019), which negatively affects this process (Zhang et al. 2016a, b). In the model, the iteration technique is considered to complete the missing parts in the evaluations (Chen et al. 2014). In addition, with the help of the consensus-based group decisionmaking methodology, the feedback mechanism is implemented and reduces the problem of opposite views about some criteria (Wu and Chiclana 2014; Dong et al. 2018; Labella et al. 2018). Moreover, a hybrid methodology is considered in the proposed model, which contributes to the objectivity of the analysis results (Zhou et al. 2020; Qiu et al. 2020; Akram et al. 2021a, b). Additionally, by using the DEMATEL method to weight the criteria, an impact relation map can be created (Yuan et al. 2020), which provides an opportunity to a conduct causality analysis between factors (Delen et al. 2020; Xie et al. 2020).

Additionally, this proposed model is appropriate to solve the problems of this study in comparison with previously developed MCDM techniques. Different criteria regarding new service development are evaluated, such as design, analysis, development, and full launch, and These factors can influence each other. Therefore, an appropriate MCDM model should be created that can both calculate the weights and identify the causal relationship among these items. Hence, the DEMATEL method is considered in this part of the evaluation rather than AHP and ANP (Yuan et al. 2020; Li et al. 2016).

Five alternatives are ranked with respect to the crowdfunding alternatives for clean energy projects: equity-based, reward-based, debt-based, royalty-based, and donation-based. In the literature, there several MCDM models (Zhang et al. 2021; Yu et al. 2021; Wang et al. 2021). For this study, the TOPSIS method is preferred due to the previously emphasized advantages (Rani et al. 2020). Furthermore, VIKOR methodology is considered to make a comparative evaluation, and the reliability of the ranking results is examined (Dhiman and Deb 2020; Ziemba et al. 2020). Moreover, using the Pythagorean fuzzy sets in the evaluation provides more reliable results because they consider membership, non-membership, and hesitancy parameters (Akram et al. 2020a, b; Ma et al. 2020; Luqman et al. 2021). Hence, it is obvious that uncertainty 
can be reflected more efficiently by PFS compared with IFS that only considers membership and non-membership degrees (Bakioglu and Atahan 2021; Peng et al. 2017; Akram et al. 2020a, b).

This proposed model has both theoretical and practical advantages. Concerning the theoretical advantage, this proposed model paves the way for the researchers and can be used for various industries. Additionally, this proposed model can be improved by researchers using other methodologies. The main theoretical limitation of this model is that a comparative evaluation has not been performed by weighting the criteria. The results obtained in this study can guide investors. As a result of the analysis, the most important service development criteria were determined and crowdfunding alternatives that are the most suitable to fund clean energy investments have been identified. Investments made using these results are likely to be more effective. However, the proposed model has not been implemented in the sector.

\section{Analysis results}

The proposed model has four stages. This section presents the analysis results for each phase.

\section{Completing the missing values of the relation matrices (phase 1)}

The first step of this section is related to the identification of the factors to evaluate the service development process and the crowdfunding alternatives for the clean energy investment projects. Concerning the service development process, four criteria are considered: design (criterion 1), analysis (criterion 2), development (criterion 3), and full launch (criterion 4). The design includes the definition of the requirements of the products and services. The analysis explains whether these requirements can be satisfied. The development provides information about the generation of the products. The full launch refers to the sale of the final product in the market.

Regarding crowdfunding alternatives for clean energy projects, five alternatives are selected: equity-based (alternative 1), reward-based (alternative 2), debt-based (alternative 3), royalty-based (alternative 4), and donation-based (alternative 5). Equity crowdfunding refers to the sale of private company securities for investment to a group of individuals. Reward-based crowdfunding is when individuals donate to a project in anticipation of receiving a non-financial reward, such as a good or service, at a later stage. Debt-based crowdfunding is when investors purchase the debt securities of the business. Corporate bonds can be an example of this alternative. Royalty-based crowdfunding returns a percentage of the income from the project. A donation-based crowdfunding system is when many participants donate small amounts. In this system, donors do not have claims or expectations from the project. For the evaluation of these criteria and alternatives, the linguistic evaluations are obtained from four decision-makers (Table 1).

Additionally, in this evaluation process, the linguistic scales and fuzzy preference numbers are considered (Table 2).

Moreover, the evaluations of the decision-makers for different crowdfunding alternatives are given in Table 3. 
Table 1 Details of decision makers

\begin{tabular}{lllll}
\hline Decision Makers & Expertise & Experience & Position & Education \\
\hline DM 1 & Financial management & 20 years & Chief of executive officer & Business engineering \\
DM 2 & Energy & 18 years & Founder & Industrial engineering \\
DM 3 & Asset management & 15 years & Senior manager & Finance \\
DM 4 & Manufacturing & 19 years & Senior vice present & Economics \\
\hline
\end{tabular}

Table 2 Linguistic scales and fuzzy preference numbers

\begin{tabular}{lll}
\hline Linguistic scales & Preference numbers & $\begin{array}{l}\text { Fuzzy } \\
\text { preferences }\end{array}$ \\
\hline No influence $(n)$ & 0 & 0 \\
weak influence $(w)$ & 1 & 0.10 \\
somewhat influence $(s)$ & 2 & 0.30 \\
medium influence $(m)$ & 3 & 0.50 \\
high influence $(h)$ & 4 & 0.70 \\
very high influence $(\mathrm{vh})$ & 5 & 0.90 \\
Extremely influence $(\mathrm{e})$ & 6 & 1 \\
\hline
\end{tabular}

In the following step, the incomplete values are calculated for constructing the full relation matrices. The computation process of the equity-based crowdfunding alternative is given for completing the missing values of the decision-makers below. For decision-maker 2 , the following iterations are made. Concerning the first iteration, the missing values of $e p_{23}$ and $e p_{32}$ are estimated. The details are given on Eqs. (51)-(58).

$$
\begin{aligned}
& \left(e p_{23}\right)^{41}=\Delta\left(\Delta^{-1}\left(p_{24}\right)+\Delta^{-1}\left(p_{43}\right)-\Delta^{-1}\left(S_{3}\right)\right)=5(\mathrm{VH}) \\
& \left(e p_{23}\right)^{42}=\Delta\left(\Delta\left(p_{43}\right)-\Delta^{-1}\left(p_{42}\right)+\Delta^{-1}\left(S_{3}\right)\right)=4(\mathrm{H}) \\
& \left(e p_{23}\right)^{43}=\Delta\left(\Delta^{-1}\left(p_{24}\right)+\Delta^{-1}\left(p_{34}\right)-\Delta^{-1}\left(S_{3}\right)\right)=3(\mathrm{M}) \\
& e p_{23}=\Delta\left(\frac{1}{3}\left(\Delta^{-1}\left(e p_{23}^{1}\right)+\Delta^{-1}\left(e p_{23}^{2}\right)+\Delta^{-1}\left(e p_{23}^{3}\right)\right)\right)=4(\mathrm{H}) \\
& \left(e p_{32}\right)^{41}=\Delta\left(\Delta^{-1}\left(p_{34}\right)+\Delta^{-1}\left(p_{42}\right)-\Delta^{-1}\left(S_{3}\right)\right)=4(\mathrm{H}) \\
& \left(e p_{32}\right)^{42}=\Delta\left(\Delta^{-1}\left(p_{42}\right)-\Delta^{-1}\left(p_{43}\right)+\Delta^{-1}\left(S_{3}\right)\right)=2(\mathrm{~S}) \\
& \left(e p_{32}\right)^{43}=\Delta\left(\Delta^{-1}\left(p_{34}\right)+\Delta^{-1}\left(p_{24}\right)-\Delta^{-1}\left(S_{3}\right)\right)=3(\mathrm{M})
\end{aligned}
$$


Table 3 Linguistic evaluations for different crowdfunding alternative

\begin{tabular}{|c|c|c|c|c|c|c|c|c|c|}
\hline \multicolumn{10}{|c|}{ Equity-based crowdfunding alternative } \\
\hline \multicolumn{5}{|c|}{ Decision Maker 1} & \multicolumn{5}{|c|}{ Decision maker 2} \\
\hline DM1 & $\mathrm{C} 1$ & $\mathrm{C} 2$ & $\mathrm{C} 3$ & $\mathrm{C} 4$ & DM2 & $\mathrm{C} 1$ & $\mathrm{C} 2$ & $\mathrm{C} 3$ & $\mathrm{C} 4$ \\
\hline $\mathrm{Cl}$ & - & M & $\mathrm{H}$ & $\mathrm{H}$ & C1 & - & $\mathrm{n} / \mathrm{a}$ & $\mathrm{H}$ & M \\
\hline $\mathrm{C} 2$ & $\mathrm{H}$ & - & M & M & $\mathrm{C} 2$ & $\mathrm{n} / \mathrm{a}$ & - & $\mathrm{n} / \mathrm{a}$ & $\mathrm{H}$ \\
\hline C3 & M & M & - & $\mathrm{VH}$ & C3 & $\mathrm{H}$ & $\mathrm{n} / \mathrm{a}$ & - & $\mathrm{H}$ \\
\hline C4 & $\mathrm{VH}$ & M & $\mathrm{H}$ & - & $\mathrm{C} 4$ & $\mathrm{H}$ & M & $\mathrm{H}$ & - \\
\hline \multicolumn{5}{|c|}{ Decision maker 3} & \multicolumn{5}{|c|}{ Decision maker 4} \\
\hline DM3 & $\mathrm{C} 1$ & $\mathrm{C2}$ & C3 & $\mathrm{C4}$ & DM4 & $\mathrm{C} 1$ & $\mathrm{C2}$ & $\mathrm{C3}$ & C4 \\
\hline $\mathrm{C} 1$ & - & $\mathrm{n} / \mathrm{a}$ & $\mathrm{H}$ & $\mathrm{VH}$ & $\mathrm{C} 1$ & - & $\mathrm{VH}$ & $\mathrm{H}$ & $\mathrm{H}$ \\
\hline $\mathrm{C} 2$ & $\mathrm{n} / \mathrm{a}$ & - & $M$ & M & $\mathrm{C} 2$ & $\mathrm{H}$ & - & M & $E$ \\
\hline C3 & $\mathrm{VH}$ & M & - & $\mathrm{VH}$ & C3 & $\mathrm{H}$ & $\mathrm{n} / \mathrm{a}$ & - & $\mathrm{H}$ \\
\hline $\mathrm{C} 4$ & M & $M$ & $\mathrm{H}$ & - & C4 & $\mathrm{n} / \mathrm{a}$ & $\mathrm{VH}$ & M & - \\
\hline
\end{tabular}

Reward-based crowdfunding alternative

\begin{tabular}{|c|c|c|c|c|c|c|c|c|c|}
\hline \multicolumn{5}{|c|}{ Decision maker 1} & \multicolumn{5}{|c|}{ Decision maker 2} \\
\hline DM1 & C1 & $\mathrm{C} 2$ & $\mathrm{C} 3$ & $\mathrm{C} 4$ & DM2 & $\mathrm{C} 1$ & $\mathrm{C} 2$ & $\mathrm{C} 3$ & $\mathrm{C4}$ \\
\hline $\mathrm{C} 1$ & - & $\mathrm{n} / \mathrm{a}$ & $\mathrm{VH}$ & M & C1 & - & $\mathrm{VH}$ & M & $\mathrm{H}$ \\
\hline $\mathrm{C} 2$ & $\mathrm{n} / \mathrm{a}$ & - & $n / a$ & $\mathrm{VH}$ & $C 2$ & $\mathrm{H}$ & - & M & $\mathrm{VH}$ \\
\hline C3 & $\mathrm{VH}$ & $\mathrm{n} / \mathrm{a}$ & - & M & $\mathrm{C} 3$ & $\mathrm{H}$ & M & - & $\mathrm{H}$ \\
\hline C4 & $\mathrm{H}$ & $\mathrm{H}$ & M & - & C4 & $\mathrm{H}$ & $\mathrm{VH}$ & $\mathrm{H}$ & - \\
\hline \multicolumn{5}{|c|}{ Decision maker 3} & \multicolumn{5}{|c|}{ Decision maker 4} \\
\hline DM3 & $\mathrm{C} 1$ & $\mathrm{C} 2$ & $\mathrm{C} 3$ & $\mathrm{C4}$ & DM4 & C1 & $\mathrm{C} 2$ & $\mathrm{C} 3$ & $\mathrm{C4}$ \\
\hline $\mathrm{C} 1$ & - & M & $\mathrm{H}$ & $\mathrm{VH}$ & $\mathrm{C} 1$ & - & $\mathrm{n} / \mathrm{a}$ & M & $E$ \\
\hline C2 & $\mathrm{H}$ & - & $\mathrm{VH}$ & $\mathrm{H}$ & C2 & $\mathrm{n} / \mathrm{a}$ & - & $\mathrm{H}$ & $E$ \\
\hline C3 & M & $\mathrm{n} / \mathrm{a}$ & - & $\mathrm{H}$ & C3 & $\mathrm{H}$ & $\mathrm{H}$ & - & $\mathrm{VH}$ \\
\hline C4 & $\mathrm{n} / \mathrm{a}$ & M & $\mathrm{H}$ & - & C4 & $M$ & $M$ & $\mathrm{H}$ & - \\
\hline
\end{tabular}

Debt-based crowdfunding alternative

\begin{tabular}{|c|c|c|c|c|c|c|c|c|c|}
\hline \multicolumn{5}{|c|}{ Decision maker 1} & \multicolumn{5}{|c|}{ Decision maker 2} \\
\hline DM1 & C1 & $C 2$ & C3 & $\mathrm{C} 4$ & $\mathrm{DM} 2$ & $\mathrm{C} 1$ & $\mathrm{C} 2$ & C3 & C4 \\
\hline $\mathrm{C} 1$ & - & $M$ & $\mathrm{H}$ & E & $\mathrm{C} 1$ & - & $\mathrm{H}$ & $\mathrm{VH}$ & $\mathrm{H}$ \\
\hline $\mathrm{C} 2$ & $\mathrm{H}$ & - & $\mathrm{E}$ & $\mathrm{H}$ & $\mathrm{C} 2$ & M & - & M & $\mathrm{H}$ \\
\hline C3 & $\mathrm{H}$ & M & - & $\mathrm{VH}$ & C3 & S & M & - & $\mathrm{H}$ \\
\hline C4 & $\mathrm{VH}$ & M & $\mathrm{H}$ & - & C4 & $\mathrm{VH}$ & $\mathrm{VH}$ & $\mathrm{VH}$ & - \\
\hline \multicolumn{5}{|c|}{ Decision maker 3} & \multicolumn{5}{|c|}{ Decision maker 4} \\
\hline DM3 & C1 & $\mathrm{C} 2$ & C3 & $\mathrm{C4}$ & DM4 & $\mathrm{C} 1$ & $\mathrm{C} 2$ & C3 & $\mathrm{C4}$ \\
\hline $\mathrm{C} 1$ & - & $\mathrm{H}$ & $M$ & $\mathrm{H}$ & $\mathrm{C} 1$ & - & $\mathrm{n} / \mathrm{a}$ & $\mathrm{VH}$ & $\mathrm{H}$ \\
\hline $\mathrm{C} 2$ & $\mathrm{VH}$ & - & $\mathrm{VH}$ & $S$ & C2 & $\mathrm{n} / \mathrm{a}$ & - & $\mathrm{H}$ & M \\
\hline C3 & $\mathrm{H}$ & $n / a$ & - & $\mathrm{VH}$ & C3 & M & M & - & $\mathrm{VH}$ \\
\hline C4 & $\mathrm{n} / \mathrm{a}$ & $\mathrm{H}$ & $\mathrm{H}$ & - & C4 & $\mathrm{H}$ & $\mathrm{VH}$ & $\mathrm{VH}$ & - \\
\hline \multicolumn{10}{|c|}{ Royalty-based crowdfunding alternative } \\
\hline \multicolumn{5}{|c|}{ Decision maker 1} & \multicolumn{5}{|c|}{ Decision maker 2} \\
\hline DM1 & C1 & $\mathrm{C2}$ & $\mathrm{C3}$ & $\mathrm{C} 4$ & $\mathrm{DM} 2$ & $\mathrm{C} 1$ & $\mathrm{C2}$ & $\mathrm{C3}$ & $\mathrm{C4}$ \\
\hline $\mathrm{C} 1$ & - & $\mathrm{VH}$ & $\mathrm{H}$ & M & $\mathrm{C} 1$ & - & M & $\mathrm{H}$ & $\mathrm{VH}$ \\
\hline
\end{tabular}


Table 3 (continued)

\begin{tabular}{|c|c|c|c|c|c|c|c|c|c|}
\hline \multicolumn{10}{|c|}{ Royalty-based crowdfunding alternative } \\
\hline \multicolumn{5}{|c|}{ Decision maker 1} & \multicolumn{5}{|c|}{ Decision maker 2} \\
\hline DM1 & $\mathrm{C} 1$ & $\mathrm{C} 2$ & $\mathrm{C} 3$ & $\mathrm{C} 4$ & DM2 & $\mathrm{C} 1$ & $\mathrm{C} 2$ & $\mathrm{C} 3$ & $\mathrm{C} 4$ \\
\hline $\mathrm{C} 2$ & E & - & $\mathrm{H}$ & $\mathrm{VH}$ & $\mathrm{C} 2$ & $\mathrm{VH}$ & - & $E$ & $\mathrm{H}$ \\
\hline $\mathrm{C} 3$ & E & $\mathrm{H}$ & - & $\mathrm{H}$ & $\mathrm{C} 3$ & $\mathrm{H}$ & $\mathrm{H}$ & - & $\mathrm{H}$ \\
\hline C4 & $\mathrm{VH}$ & $\mathrm{VH}$ & $\mathrm{H}$ & - & $\mathrm{C} 4$ & $\mathrm{VH}$ & $\mathrm{H}$ & M & - \\
\hline \multicolumn{5}{|c|}{ Decision maker 3} & \multicolumn{5}{|c|}{ Decision maker 4} \\
\hline DM3 & $\mathrm{C} 1$ & $\mathrm{C} 2$ & C3 & $\mathrm{C} 4$ & DM4 & C1 & $\mathrm{C} 2$ & C3 & C4 \\
\hline C1 & - & VH & $\mathrm{M}$ & $\mathrm{H}$ & $\mathrm{C} 1$ & - & $\mathrm{n} / \mathrm{a}$ & $\mathrm{H}$ & $\mathrm{H}$ \\
\hline $\mathrm{C} 2$ & $M$ & - & $\mathrm{H}$ & $\mathrm{M}$ & C2 & $\mathrm{n} / \mathrm{a}$ & - & $\mathrm{H}$ & $M$ \\
\hline C3 & $\mathrm{VH}$ & $\mathrm{n} / \mathrm{a}$ & - & $M$ & C3 & $\mathrm{VH}$ & $\mathrm{H}$ & - & $\mathrm{H}$ \\
\hline C4 & $\mathrm{n} / \mathrm{a}$ & $S$ & $\mathrm{VH}$ & - & C4 & $E$ & E & $\mathrm{H}$ & - \\
\hline
\end{tabular}

Donation-based crowdfunding alternative

\begin{tabular}{|c|c|c|c|c|c|c|c|c|c|}
\hline \multicolumn{5}{|c|}{ Decision maker 1} & \multicolumn{5}{|c|}{ Decision maker 2} \\
\hline DM1 & C1 & $\mathrm{C} 2$ & $\mathrm{C} 3$ & $\mathrm{C} 4$ & DM2 & C1 & $\mathrm{C} 2$ & $\mathrm{C} 3$ & $\mathrm{C} 4$ \\
\hline $\mathrm{C} 1$ & - & $\mathrm{H}$ & $M$ & $\mathrm{VH}$ & $\mathrm{C} 1$ & - & $\mathrm{H}$ & $\mathrm{H}$ & $\mathrm{VH}$ \\
\hline $\mathrm{C} 2$ & $\mathrm{VH}$ & - & $\mathrm{H}$ & $\mathrm{H}$ & C2 & E & - & $\mathrm{H}$ & $\mathrm{VH}$ \\
\hline C3 & $\mathrm{H}$ & M & - & $M$ & $\mathrm{C} 3$ & $\mathrm{H}$ & $\mathrm{n} / \mathrm{a}$ & - & M \\
\hline C4 & $\mathrm{H}$ & $\mathrm{H}$ & $\mathrm{VH}$ & - & C4 & $\mathrm{n} / \mathrm{a}$ & M & $\mathrm{H}$ & - \\
\hline \multicolumn{5}{|c|}{ Decision maker 3} & \multicolumn{5}{|c|}{ Decision maker 4} \\
\hline DM3 & C1 & $\mathrm{C2}$ & $\mathrm{C3}$ & C4 & DM4 & C1 & $\mathrm{C2}$ & C3 & $\mathrm{C4}$ \\
\hline $\mathrm{C} 1$ & - & $\mathrm{H}$ & $M$ & $\mathrm{~S}$ & C1 & - & $\mathrm{VH}$ & $\mathrm{H}$ & M \\
\hline C2 & $\mathrm{H}$ & - & $\mathrm{H}$ & $\mathrm{H}$ & C2 & $E$ & - & $\mathrm{H}$ & $\mathrm{VH}$ \\
\hline C3 & $\mathrm{H}$ & $\mathrm{H}$ & - & $\mathrm{H}$ & C3 & $\mathrm{VH}$ & $\mathrm{H}$ & - & $\mathrm{H}$ \\
\hline C4 & $M$ & VH & $\mathrm{H}$ & - & C4 & $\mathrm{H}$ & $\mathrm{H}$ & $\mathrm{H}$ & - \\
\hline
\end{tabular}

$$
e p_{32}=\Delta\left(\frac{1}{3}\left(\Delta^{-1}\left(e p_{32}^{1}\right)+\Delta^{-1}\left(e p_{32}^{2}\right)+\Delta^{-1}\left(e p_{32}^{3}\right)\right)\right)=3(\mathrm{M})
$$

The second iteration includes the estimations for $e p_{12}$ and $e p_{21}$. The details are demonstrated in Eqs. (59)-(66).

$$
\begin{aligned}
& \left(e p_{12}\right)^{31}=\Delta\left(\Delta^{-1}\left(p_{13}\right)+\Delta^{-1}\left(p_{32}\right)-\Delta^{-1}\left(S_{3}\right)\right)=4(\mathrm{H}) \\
& \left(e p_{12}\right)^{32}=\Delta\left(\Delta^{-1}\left(p_{32}\right)-\Delta^{-1}\left(p_{31}\right)+\Delta^{-1}\left(S_{3}\right)\right)=2(\mathrm{~S}) \\
& \left(e p_{12}\right)^{33}=\left(\Delta^{-1}\left(p_{13}\right)+\Delta^{-1}\left(p_{23}\right)-\Delta^{-1}\left(S_{3}\right)\right)=3(\mathrm{M}) \\
& e p_{12}=\Delta\left(\frac{1}{3}\left(\Delta^{-1}\left(e p_{12}^{1}\right)+\Delta^{-1}\left(e p_{12}^{2}\right)+\Delta^{-1}\left(e p_{12}^{3}\right)\right)\right)=3(\mathrm{M})
\end{aligned}
$$




$$
\begin{aligned}
& \left(e p_{21}\right)^{31}=\Delta\left(\Delta^{-1}\left(p_{23}\right)+\Delta^{-1}\left(p_{31}\right)-\Delta^{-1}\left(S_{3}\right)\right)=5(\mathrm{VH}) \\
& \left(e p_{21}\right)^{32}=\Delta\left(\Delta^{-1}\left(p_{31}\right)-\Delta^{-1}\left(p_{32}\right)+\Delta^{-1}\left(S_{3}\right)\right)=4(\mathrm{H}) \\
& \left(e p_{21}\right)^{33}=\Delta\left(\Delta^{-1}\left(p_{23}\right)+\Delta^{-1}\left(p_{13}\right)-\Delta^{-1}\left(S_{3}\right)\right)=3(\mathrm{M}) \\
& e p_{21}=\Delta\left(\frac{1}{3}\left(\Delta^{-1}\left(e p_{21}^{1}\right)+\Delta^{-1}\left(e p_{21}^{2}\right)+\Delta^{-1}\left(e p_{21}^{3}\right)\right)\right)=4(\mathrm{H})
\end{aligned}
$$

For decision-maker 3, the iterations of $e p_{12}$ and $e p_{21}$ are demonstrated in Eqs. (67)-(74).

$$
\begin{aligned}
& \left(e p_{12}\right)^{31}=4(\mathrm{H}) \\
& \left(e p_{12}\right)^{32}=1(\mathrm{~W}) \\
& \left(e p_{12}\right)^{33}=4(\mathrm{H}) \\
& e p_{12}=3(\mathrm{M}) \\
& \left(e p_{21}\right)^{31}=5(\mathrm{VH}) \\
& \left(e p_{21}\right)^{32}=5(\mathrm{VH}) \\
& \left(e p_{21}\right)^{33}=2(\mathrm{~S}) \\
& e p_{21}=4(\mathrm{H})
\end{aligned}
$$

Regarding decision-maker 4 , the iterations of $e p_{32}$ and $e p_{41}$ are indicated in Eqs. (75)-(82).

$$
\begin{aligned}
& \left(e p_{32}\right)^{41}=6(\mathrm{E}) \\
& \left(e p_{32}\right)^{42}=5(\mathrm{VH}) \\
& \left(e p_{32}\right)^{43}=1(\mathrm{~W}) \\
& e p_{32}=4(\mathrm{H}) \\
& \left(e p_{41}\right)^{31}=4(\mathrm{H}) \\
& \left(e p_{41}\right)^{32}=3(\mathrm{M})
\end{aligned}
$$




$$
\begin{aligned}
& \left(e p_{41}\right)^{33}=2(\mathrm{~S}) \\
& e p_{41}=3(\mathrm{M})
\end{aligned}
$$

Similar estimation procedures are applied for the missing values of the other crowdfunding alternatives. The computed values of the alternatives are represented for the missing values of the decision-makers as follows. The estimated values are given for the missing items of reward-based crowdfunding alternative as in Eq. (83) for decisionmaker 1, in Eq. (84) for decision-maker 3, and in Eq. (85) for decision-maker 4.

$$
\begin{aligned}
& e p_{12}=3(\mathrm{M}), e p_{21}=4(\mathrm{H}), e p_{23}=4(\mathrm{H}), e p_{32}=3(\mathrm{M}) \\
& e p_{32}=3(\mathrm{M}), e p_{41}=3(\mathrm{M}) \\
& e p_{12}=3(\mathrm{M}), e p_{21}=4(\mathrm{H})
\end{aligned}
$$

Moreover, the computed values are presented by the estimated values of the decisionmakers for the debt-based crowdfunding alternative. Equations (86) and (87) are considered for decision-makers 3 and 4, respectively.

$$
\begin{aligned}
& e p_{32}=5(\mathrm{VH}), e p_{41}=4(\mathrm{H}) \\
& e p_{12}=3(\mathrm{M}), e p_{21}=3(\mathrm{M})
\end{aligned}
$$

Furthermore, the missing values are calculated for the royalty-based crowdfunding alternative as in Eqs. (88) and (89) for decision-makers 1 and 2, respectively.

$$
\begin{aligned}
& e p_{32}=4(\mathrm{H}), e p_{41}=5(\mathrm{VH}) \\
& e p_{12}=3(\mathrm{M}), e p_{21}=5(\mathrm{VH})
\end{aligned}
$$

Finally, the estimation results of the missing values are represented for the donationbased crowdfunding alternative by the following values. Concerning decision-maker 2, Eq. (90) is taken into consideration.

$$
e p_{32}=2(\mathrm{~S}), e p_{41}=4(\mathrm{H})
$$

\section{Determining the consensus-based fuzzy preferences for the criteria of the crowdfunding alternatives (phase 2)}

The first step in this phase includes the construction of the corresponding fuzzy preference relations. The details for the equity-based crowdfunding alternative are demonstrated in Table 4. In this process, the calculation details of the equity-based crowdfunding alternative are shown. Only the results are given for other alternatives.

In the following step, the consistency levels are calculated. Table 5 outlines the details for the equity-based crowdfunding alternative.

The global consistency level (GCL) is computed as 0.91 for the equity-based crowdfunding alternative. Similar steps are employed for the other alternatives and the 
Table 4 Corresponding fuzzy preference relations for the equity-based crowdfunding alternative

\begin{tabular}{|c|c|c|c|c|c|c|c|c|c|}
\hline \multicolumn{5}{|c|}{ Decision maker 1} & \multicolumn{5}{|c|}{ Decision maker 2} \\
\hline $\mathrm{CP} 1$ & $\mathrm{C} 1$ & $\mathrm{C} 2$ & $\mathrm{C3}$ & $\mathrm{C} 4$ & $\mathrm{CP2}$ & C1 & $\mathrm{C2}$ & C3 & $\mathrm{C} 4$ \\
\hline $\mathrm{C} 1$ & - & 0.57 & 0.47 & 0.63 & C1 & - & 0.43 & 0.53 & 0.60 \\
\hline $\mathrm{C} 2$ & 0.57 & - & 0.63 & 0.67 & $\mathrm{C} 2$ & 0.73 & - & 0.70 & 0.63 \\
\hline C3 & 0.77 & 0.53 & - & 0.47 & $\mathrm{C} 3$ & 0.63 & 0.50 & - & 0.53 \\
\hline C4 & 0.53 & 0.57 & 0.67 & - & C4 & 0.60 & 0.53 & 0.63 & - \\
\hline \multicolumn{5}{|c|}{ Decision maker 3} & \multicolumn{5}{|c|}{ Decision maker 4} \\
\hline $\mathrm{CP3}$ & C1 & $\mathrm{C} 2$ & $\mathrm{C3}$ & $\mathrm{C} 4$ & $\mathrm{CP} 4$ & C1 & $\mathrm{C2}$ & C3 & $\mathrm{C} 4$ \\
\hline $\mathrm{C} 1$ & - & 0.63 & 0.60 & 0.57 & $\mathrm{C} 1$ & - & 0.72 & 0.60 & 0.80 \\
\hline$C 2$ & 0.53 & - & 0.57 & 0.80 & $\mathrm{C} 2$ & 0.57 & - & 0.60 & 0.60 \\
\hline C3 & 0.60 & 0.67 & - & 0.73 & C3 & 0.60 & 0.75 & - & 0.77 \\
\hline $\mathrm{C} 4$ & 0.67 & 0.40 & 0.43 & - & C4 & 0.55 & 0.60 & 0.52 & - \\
\hline
\end{tabular}

Table 5 Consistency levels for the equity-based crowdfunding alternative

\begin{tabular}{|c|c|c|c|c|c|c|c|c|c|}
\hline \multicolumn{5}{|c|}{ Decision maker 1 (CL1:0.89) } & \multicolumn{5}{|c|}{ Decision maker 2 (CL2:0.95) } \\
\hline $\mathrm{CL} 1$ & $\mathrm{C} 1$ & $\mathrm{C} 2$ & $\mathrm{C} 3$ & $\mathrm{C} 4$ & $\mathrm{CL} 2$ & $\mathrm{C} 1$ & $\mathrm{C} 2$ & $\mathrm{C} 3$ & $\mathrm{C} 4$ \\
\hline $\mathrm{C} 1$ & - & 0.96 & 0.84 & 0.96 & C1 & - & 0.96 & 0.89 & 0.93 \\
\hline$C 2$ & 0.91 & - & 0.91 & 0.89 & $\mathrm{C} 2$ & 0.98 & - & 1.00 & 0.96 \\
\hline C3 & 0.82 & 0.98 & - & 0.71 & C3 & 0.96 & 1.00 & - & 0.89 \\
\hline $\mathrm{C} 4$ & 0.76 & 0.96 & 0.98 & - & C4 & 0.93 & 0.98 & 0.96 & - \\
\hline \multicolumn{5}{|c|}{ Decision maker 3 (CL3:0.87) } & \multicolumn{5}{|c|}{ Decision maker 4 (CL4:0.91) } \\
\hline CL3 & $\mathrm{C} 1$ & $\mathrm{C} 2$ & $\mathrm{C} 3$ & $\mathrm{C} 4$ & CL4 & $\mathrm{C} 1$ & $\mathrm{C2}$ & $\mathrm{C} 3$ & $\mathrm{C} 4$ \\
\hline $\mathrm{C} 1$ & - & 0.91 & 0.93 & 0.78 & $\mathrm{C} 1$ & - & 0.88 & 0.93 & 0.93 \\
\hline C2 & 0.89 & - & 0.96 & 0.80 & $\mathrm{C} 2$ & 0.91 & - & 0.93 & 0.73 \\
\hline C3 & 0.80 & 0.89 & - & 0.89 & C3 & 0.93 & 0.97 & - & 0.96 \\
\hline C4 & 0.89 & 0.93 & 0.82 & - & C4 & 0.97 & 0.80 & 0.99 & - \\
\hline
\end{tabular}

values of GCL are $0.91,0.88,0.87$, and 0.90 for the reward-based, debt-based, royalty-based, and donation-based crowdfunding alternatives, respectively. Then, the similarity matrices are computed, and the results are illustrated in Table 6 for the equity-based crowdfunding alternative.

Additionally, Table 7 demonstrates the collective similarity matrix for the equitybased crowdfunding alternative.

Afterward, the consensual degrees are identified. The global consensus degree (CR) is calculated as 0.85 for the equity-based crowdfunding alternative. Accordingly, the same procedures are applied for the remaining alternatives. The results are given as $0.82,0.82,0.81$, and 0.84 for the reward-based, debt-based, royalty-based, and donation-based crowdfunding alternatives, respectively. Table 8 outlines the consensual fuzzy preference degrees for the equity-based crowdfunding alternative.

The collective fuzzy preference relations for the equity-based crowdfunding alternative are given in Table 9. 
Table 6 Similarity matrices for the equity-based crowdfunding alternative

\begin{tabular}{|c|c|c|c|c|c|c|c|c|c|}
\hline \multicolumn{5}{|c|}{ DM1-DM3 } & \multicolumn{5}{|c|}{ DM1-DM4 } \\
\hline SM13 & $\mathrm{C} 1$ & $\mathrm{C2}$ & C3 & $\mathrm{C} 4$ & SM14 & $\mathrm{C} 1$ & $\mathrm{C} 2$ & C3 & $\mathrm{C} 4$ \\
\hline $\mathrm{C} 1$ & & 1.00 & 1.00 & 0.80 & $\mathrm{C} 1$ & & 0.60 & 1.00 & 1.00 \\
\hline $\mathrm{C} 2$ & 1.00 & & 1.00 & 1.00 & $\mathrm{C} 2$ & 1.00 & & 1.00 & 0.50 \\
\hline C3 & 0.60 & 1.00 & & 1.00 & C3 & 0.80 & 0.80 & & 0.80 \\
\hline $\mathrm{C} 4$ & 0.60 & 1.00 & 1.00 & & $\mathrm{C} 4$ & 0.60 & 0.60 & 0.80 & \\
\hline \multicolumn{5}{|c|}{ DM2-DM3 } & \multicolumn{5}{|c|}{ DM2-DM4 } \\
\hline SM23 & $\mathrm{C} 1$ & $\mathrm{C2}$ & C3 & $\mathrm{C4}$ & SM24 & C1 & $\mathrm{C2}$ & C3 & C4 \\
\hline $\mathrm{C} 1$ & & 1.00 & 1.00 & 0.60 & $\mathrm{C} 1$ & & 0.60 & 1.00 & 0.80 \\
\hline $\mathrm{C} 2$ & 1.00 & & 0.80 & 0.80 & $C 2$ & 1.00 & & 0.80 & 0.70 \\
\hline C3 & 0.80 & 1.00 & & 0.80 & $\mathrm{C} 3$ & 1.00 & 0.80 & & 1.00 \\
\hline $\mathrm{C} 4$ & 0.80 & 1.00 & 1.00 & & C4 & 0.80 & 0.60 & 0.80 & \\
\hline
\end{tabular}

Table 7 Collective similarity matrix for the equity-based crowdfunding alternative

\begin{tabular}{lllll}
\hline SM & C1 & C2 & C3 & C4 \\
\hline C1 & & 0.80 & 1.00 & 0.80 \\
C2 & 1.00 & & 0.90 & 0.75 \\
C3 & 0.80 & 0.90 & & 0.90 \\
C4 & 0.70 & 0.80 & 0.90 & \\
\hline
\end{tabular}

Table 8 Consensual fuzzy preference degrees for the equity-based crowdfunding alternative

\begin{tabular}{|c|c|c|c|c|c|c|c|c|c|}
\hline \multicolumn{5}{|c|}{ Decision maker 1} & \multicolumn{5}{|c|}{ Decision maker 2} \\
\hline $\mathrm{Z1}$ & C1 & $\mathrm{C} 2$ & $\mathrm{C3}$ & $\mathrm{C} 4$ & $\mathrm{Z2}$ & C1 & $\mathrm{C2}$ & $\mathrm{C3}$ & $\mathrm{C} 4$ \\
\hline $\mathrm{C} 1$ & & 0.93 & 0.85 & 0.67 & $\mathrm{C} 1$ & & 0.91 & 0.89 & 0.70 \\
\hline C2 & 0.86 & & 0.99 & 0.90 & $\mathrm{C} 2$ & 0.86 & & 0.97 & 0.88 \\
\hline C3 & 0.92 & 0.84 & & 0.87 & $\mathrm{C} 3$ & 0.92 & 0.73 & & 0.87 \\
\hline C4 & 0.93 & 0.88 & 0.79 & & $\mathrm{C} 4$ & 0.94 & 0.79 & 0.93 & \\
\hline \multicolumn{5}{|c|}{ Decision maker 3} & \multicolumn{5}{|c|}{ Decision maker 4} \\
\hline $\mathrm{Z3}$ & C1 & $\mathrm{C} 2$ & $\mathrm{C3}$ & $\mathrm{C} 4$ & $\mathrm{Z4}$ & C1 & $\mathrm{C2}$ & $\mathrm{C3}$ & $\mathrm{C} 4$ \\
\hline $\mathrm{C} 1$ & & 0.92 & 0.89 & 0.61 & $\mathrm{C} 1$ & & 0.78 & 0.88 & 0.72 \\
\hline $\mathrm{C} 2$ & 0.79 & & 0.97 & 0.87 & $\mathrm{C} 2$ & 0.87 & & 0.99 & 0.86 \\
\hline C3 & 0.94 & 0.84 & & 0.87 & $\mathrm{C} 3$ & 0.82 & 0.85 & & 0.90 \\
\hline C4 & 0.81 & 0.76 & 0.94 & & $\mathrm{C} 4$ & 0.94 & 0.90 & 0.93 & \\
\hline
\end{tabular}

Table 9 Collective fuzzy preference relations for the equity-based crowdfunding alternative

\begin{tabular}{lllll}
\hline $\mathbf{P}$ & $\mathbf{C 1}$ & $\mathbf{C 2}$ & $\mathbf{C 3}$ & $\mathbf{C 4}$ \\
\hline C1 & & 0.90 & 0.87 & 0.68 \\
$\mathrm{C2}$ & 0.85 & & 0.99 & 0.89 \\
C3 & 0.90 & 0.82 & & 0.88 \\
C4 & 0.92 & 0.85 & 0.86 & \\
\hline
\end{tabular}


In the next step, the proximity levels are defined. These values are defined for the equity-based crowdfunding alternative in Table 10.

In the final step, the feedback mechanism is applied to check the consensus control level (CCL). The values of CCL are determined 0.87, 0.84, 0.83, 0.83, and 0.85 for the equity-based, reward-based, debt-based, royalty-based, and donation-based alternatives, respectively. The feedback mechanism is applied by checking the values of CCL to determine if it is equal to or greater than 0.85 . The equity-based and the donation-based crowdfunding alternatives (alternatives 1 and 5) satisfy the consensusbased fuzzy relation evaluations. However, the second-round feedback mechanism is applied to check the modified evaluations of the group decision-making approach for the reward-based, debt-based, and royalty-based alternatives (alternatives 2, 3, and 4).

The CCL values for the second round are computed as $0.85,0.85$, and 0.83 for the reward-based, debt-based, and royalty-based alternatives (alternatives 2,3 , and 4), respectively. The reward and debt-based alternatives (alternatives 2 and 3) reach the consensus in the group decision-making process, but the result of the royaltybased crowdfunding alternative does not exceed the threshold value of 0.85 . So, the third-round computation process should be continued for the royalty-based alternative (alternative 4). The third-round CCL result is 0.86 for the royalty-based alternative. Accordingly, regarding the first-round evaluation, the consensus-based fuzzy preference relation results for the equity-based crowdfunding alternative are given in Table 11.

Additionally, Table 12 outlines the second-round evaluation results.

The consensus-based fuzzy preference relations for the debt-based crowdfunding alternative of the second-round evaluation are indicated in Table 13.

Additionally, Table 14 indicates the third-round evaluation of the consensus-based fuzzy preference relations for the royalty-based crowdfunding alternative.

The first-round evaluation concerning the consensus-based fuzzy preference relations for the donation-based crowdfunding alternative is shown in Table 15.

Table 10 Proximity levels for the equity-based crowdfunding alternative

\begin{tabular}{|c|c|c|c|c|c|c|c|c|c|}
\hline \multicolumn{5}{|c|}{ Decision maker $1\left(\operatorname{Pr}^{1}: 0.78\right)$} & \multicolumn{5}{|c|}{ Decision maker $2\left(\mathrm{Pr}^{2}: 0.76\right)$} \\
\hline $\mathrm{PP}^{1}$ & C1 & $\mathrm{C} 2$ & C3 & C4 & $\mathrm{PP}^{2}$ & C1 & $\mathrm{C} 2$ & C3 & C4 \\
\hline $\mathrm{C} 1$ & & 0.80 & 0.63 & 0.78 & $\mathrm{C} 1$ & & 0.80 & 0.83 & 0.78 \\
\hline $\mathrm{C} 2$ & 0.95 & & 0.71 & 0.81 & $\mathrm{C} 2$ & 0.85 & & 0.71 & 0.99 \\
\hline $\mathrm{C} 3$ & 0.80 & 0.68 & & 0.62 & $\mathrm{C} 3$ & 0.80 & 0.48 & & 0.62 \\
\hline C4 & 0.78 & 0.85 & 0.96 & & C4 & 0.78 & 0.65 & 0.84 & \\
\hline \multicolumn{5}{|c|}{ Decision maker $3\left(\mathrm{Pr}^{3}: 0.77\right)$} & \multicolumn{5}{|c|}{ Decision maker $4\left(\mathrm{Pr}^{4}: 0.86\right)$} \\
\hline$\overline{\mathrm{PP}^{3}}$ & C1 & $\mathrm{C2}$ & C3 & C4 & $\mathrm{PP}^{4}$ & $\mathrm{C} 1$ & $\mathrm{C2}$ & $\mathrm{C3}$ & $\mathrm{C} 4$ \\
\hline $\mathrm{C} 1$ & & 0.80 & 0.63 & 0.62 & $\mathrm{C} 1$ & & 1.00 & 0.83 & 0.82 \\
\hline $\mathrm{C} 2$ & 0.85 & & 0.71 & 0.81 & $\mathrm{C} 2$ & 0.85 & & 0.71 & 0.99 \\
\hline C3 & 0.80 & 0.88 & & 0.82 & C3 & 1.00 & 0.88 & & 0.82 \\
\hline C4 & 0.58 & 0.95 & 0.84 & & C4 & 0.78 & 0.85 & 0.84 & \\
\hline
\end{tabular}


Table 11 Consensus-based fuzzy preference relations for the equity-based crowdfunding alternative (the first-round evaluation)

\begin{tabular}{|c|c|c|c|c|c|c|c|c|c|}
\hline \multicolumn{5}{|c|}{ Decision maker 1} & \multicolumn{5}{|c|}{ Decision maker 2} \\
\hline $\mathrm{P}^{1}$ & $\mathrm{C1}$ & $\mathrm{C2}$ & $\mathrm{C3}$ & C4 & $\mathrm{P}^{2}$ & C1 & $\mathrm{C2}$ & $\mathrm{C3}$ & C4 \\
\hline $\mathrm{C} 1$ & - & 0.50 & 0.70 & 0.70 & $\mathrm{C} 1$ & - & 0.50 & 0.70 & 0.50 \\
\hline$C 2$ & 0.70 & - & 0.50 & 0.50 & $C 2$ & 0.70 & - & 0.70 & 0.70 \\
\hline $\mathrm{C} 3$ & 0.50 & 0.50 & - & 0.90 & $\mathrm{C} 3$ & 0.70 & 0.50 & - & 0.70 \\
\hline C4 & 0.90 & 0.50 & 0.70 & - & $\mathrm{C} 4$ & 0.70 & 0.50 & 0.70 & \\
\hline \multicolumn{5}{|c|}{ Decision maker 3} & \multicolumn{5}{|c|}{ Decision maker 4} \\
\hline$P^{3}$ & $\mathrm{C} 1$ & $\mathrm{C2}$ & $\mathrm{C3}$ & C4 & $\overline{\mathrm{P}^{4}}$ & C1 & $\mathrm{C2}$ & $\mathrm{C3}$ & $\mathrm{C4}$ \\
\hline $\mathrm{C} 1$ & - & 0.50 & 0.70 & 0.90 & $\mathrm{C} 1$ & - & 0.90 & 0.70 & 0.70 \\
\hline $\mathrm{C} 2$ & 0.70 & - & 0.50 & 0.50 & $\mathrm{C} 2$ & 0.70 & - & 0.50 & 1.00 \\
\hline C3 & 0.90 & 0.50 & - & 0.90 & C3 & 0.70 & 0.70 & - & 0.70 \\
\hline C4 & 0.50 & 0.50 & 0.70 & - & C4 & 0.50 & 0.90 & 0.50 & - \\
\hline
\end{tabular}

Table 12 Consensus-based fuzzy preference relations for the reward-based crowdfunding alternative (the second-round evaluation)

\begin{tabular}{|c|c|c|c|c|c|c|c|c|c|}
\hline \multicolumn{5}{|c|}{ Decision maker 1} & \multicolumn{5}{|c|}{ Decision maker 2} \\
\hline$P^{1}$ & $\mathrm{C} 1$ & $\mathrm{C} 2$ & $\mathrm{C3}$ & $\mathrm{C} 4$ & $\mathrm{P}^{2}$ & $\mathrm{C1}$ & $\mathrm{C2}$ & $\mathrm{C3}$ & $\mathrm{C} 4$ \\
\hline $\mathrm{C} 1$ & - & 0.50 & 0.90 & 0.50 & $\mathrm{C} 1$ & - & 0.90 & 0.50 & 0.70 \\
\hline $\mathrm{C} 2$ & 0.70 & - & 0.70 & 0.90 & $\mathrm{C} 2$ & 0.70 & - & 0.78 & 0.90 \\
\hline C3 & 0.90 & 0.82 & - & 0.77 & $\mathrm{C} 3$ & 0.70 & 0.88 & - & 0.70 \\
\hline $\mathrm{C} 4$ & 0.70 & 0.70 & 0.50 & - & $\mathrm{C} 4$ & 0.70 & 0.90 & 0.70 & - \\
\hline \multicolumn{5}{|c|}{ Decision maker 3} & \multicolumn{5}{|c|}{ Decision maker 4} \\
\hline $\mathrm{P}^{3}$ & $\mathrm{C} 1$ & $\mathrm{C} 2$ & $\mathrm{C} 3$ & $\mathrm{C} 4$ & $\overline{\mathrm{P}^{4}}$ & $\mathrm{C} 1$ & $\mathrm{C} 2$ & C3 & $\overline{C 4}$ \\
\hline $\mathrm{C} 1$ & - & 0.78 & 0.70 & 0.90 & $\mathrm{C} 1$ & - & 0.78 & 0.50 & 1.00 \\
\hline $\mathrm{C} 2$ & 0.70 & - & 0.90 & 0.70 & $\mathrm{C} 2$ & 0.70 & - & 0.70 & 1.00 \\
\hline C3 & 0.50 & 0.50 & - & 0.70 & $\mathrm{C} 3$ & 0.70 & 0.70 & - & 0.90 \\
\hline $\mathrm{C} 4$ & 0.50 & 0.50 & 0.70 & - & C4 & 0.81 & 0.50 & 0.70 & - \\
\hline
\end{tabular}

\section{Evaluating the service development process of clean energy investment projects}

by the crowdfunding alternatives with pythagorean fuzzy sets (phase 3 )

The first step of this phase is related to the construction of the Pythagorean fuzzy relation matrix. The normalized matrix is constructed by considering the boundaries of $\mu_{p}^{2}+n_{p}^{2}=1$. Table 16 illustrates the fuzzy relation matrix for the equity-based crowdfunding alternative.

The following steps show the computation results of Pythagorean fuzzy DEMATEL for the equity-based crowdfunding alternative. Table 17 outlines the defuzzified relation matrix for the equity-based crowdfunding alternative.

The matrix is normalized as in Table 18.

Then, the total relation matrix is constructed by considering these variables. This new matrix is developed as in Table 19. 
Table 13 Consensus-based fuzzy preference relations for the debt-based crowdfunding alternative (the second-round evaluation)

\begin{tabular}{|c|c|c|c|c|c|c|c|c|c|}
\hline \multicolumn{5}{|c|}{ Decision maker 1} & \multicolumn{5}{|c|}{ Decision maker 2} \\
\hline $\mathrm{P}^{1}$ & $\mathrm{C1}$ & $\mathrm{C2}$ & $\mathrm{C3}$ & C4 & $\mathrm{P}^{2}$ & C1 & $\mathrm{C2}$ & $\mathrm{C3}$ & C4 \\
\hline $\mathrm{C} 1$ & - & 0.50 & 0.70 & 1.00 & $\mathrm{C} 1$ & - & 0.70 & 0.90 & 0.70 \\
\hline$C 2$ & 0.70 & - & 0.72 & 0.70 & $C 2$ & 0.50 & - & 0.50 & 0.70 \\
\hline $\mathrm{C} 3$ & 0.70 & 0.50 & - & 0.90 & $\mathrm{C} 3$ & 0.75 & 0.78 & - & 0.70 \\
\hline C4 & 0.90 & 0.50 & 0.70 & - & $\mathrm{C} 4$ & 0.90 & 0.90 & 0.90 & - \\
\hline \multicolumn{5}{|c|}{ Decision maker 3} & \multicolumn{5}{|c|}{ Decision maker 4} \\
\hline$P^{3}$ & $\mathrm{C} 1$ & $\mathrm{C2}$ & $\mathrm{C3}$ & C4 & $\overline{\mathrm{P}^{4}}$ & $\mathrm{C} 1$ & $\mathrm{C2}$ & $\mathrm{C3}$ & $\mathrm{C4}$ \\
\hline C1 & - & 0.70 & 0.50 & 0.70 & $\mathrm{C} 1$ & - & 0.86 & 0.90 & 0.70 \\
\hline $\mathrm{C} 2$ & 0.90 & - & 0.90 & 0.80 & $\mathrm{C} 2$ & 0.50 & - & 0.70 & 0.50 \\
\hline C3 & 0.70 & 0.90 & - & 0.90 & C3 & 0.50 & 0.50 & - & 0.90 \\
\hline C4 & 0.70 & 0.70 & 0.70 & - & C4 & 0.70 & 0.90 & 0.90 & - \\
\hline
\end{tabular}

Table 14 Consensus-based fuzzy preference relations for the royalty-based crowdfunding alternative (the third-round evaluation)

\begin{tabular}{|c|c|c|c|c|c|c|c|c|c|}
\hline \multicolumn{5}{|c|}{ Decision maker 1} & \multicolumn{5}{|c|}{ Decision maker 2} \\
\hline P1 & $\mathrm{C} 1$ & $\mathrm{C} 2$ & $\mathrm{C3}$ & $\mathrm{C} 4$ & P2 & $\mathrm{C1}$ & $\mathrm{C2}$ & $\mathrm{C3}$ & $\mathrm{C4}$ \\
\hline C1 & - & 0.90 & 0.70 & 0.76 & $\mathrm{C} 1$ & - & 0.50 & 0.70 & 0.90 \\
\hline $\mathrm{C} 2$ & 1.00 & - & 0.70 & 0.90 & $\mathrm{C} 2$ & 0.90 & - & 1.00 & 0.70 \\
\hline $\mathrm{C} 3$ & 1.00 & 0.94 & - & 0.70 & $\mathrm{C} 3$ & 0.70 & 0.88 & - & 0.70 \\
\hline $\mathrm{C} 4$ & 0.90 & 0.90 & 0.70 & - & $\mathrm{C} 4$ & 0.90 & 0.70 & 0.50 & - \\
\hline \multicolumn{5}{|c|}{ Decision maker 3} & \multicolumn{5}{|c|}{ Decision maker 4} \\
\hline P3 & $\mathrm{C} 1$ & $\mathrm{C} 2$ & $\mathrm{C} 3$ & $\mathrm{C} 4$ & $\mathrm{P4}$ & $\mathrm{C} 1$ & $\mathrm{C} 2$ & $\mathrm{C3}$ & $\mathrm{C} 4$ \\
\hline C1 & - & 0.90 & 0.50 & 0.70 & $\mathrm{C} 1$ & - & 0.50 & 0.70 & 0.70 \\
\hline $\mathrm{C} 2$ & 0.50 & - & 0.70 & 0.50 & $\mathrm{C} 2$ & 0.70 & - & 0.70 & 0.50 \\
\hline C3 & 0.90 & 0.70 & - & 0.87 & $\mathrm{C} 3$ & 0.90 & 0.91 & - & 0.70 \\
\hline $\mathrm{C} 4$ & 0.70 & 0.30 & 0.90 & - & C4 & 1.00 & 0.69 & 0.70 & - \\
\hline
\end{tabular}

Finally, the values of $\mathrm{D}$ and $\mathrm{E}$ along with the weights of the service development process are calculated (Table 20).

Table 20 indicates that, with respect to the equity-based crowdfunding alternative, full launch (criterion 4) is the most significant factor because it has the highest weight. Additionally, design (criterion 1) is important. For reward-based crowdfunding alternative, analysis (criterion 2) plays the most significant role, and full launch (criterion 4) should be considered for this alternative. Furthermore, full launch (criterion 4) has the highest importance regarding debt-based crowdfunding alternatives. For the royalty-based alternative, design (criterion 1) is the most essential item. Finally, analysis (criterion 2) should be considered mainly when the donationbased crowdfunding alternative is preferred. 
Table 15 Consensus-based fuzzy preference relations for the donation-based crowdfunding alternative (the first-round evaluation)

\begin{tabular}{|c|c|c|c|c|c|c|c|c|c|}
\hline \multicolumn{5}{|c|}{ Decision maker 1} & \multicolumn{5}{|c|}{ Decision maker 2} \\
\hline P1 & $\mathrm{C} 1$ & $\mathrm{C} 2$ & $\mathrm{C3}$ & $\mathrm{C4}$ & P2 & $\mathrm{C} 1$ & $\mathrm{C} 2$ & C3 & $\mathrm{C} 4$ \\
\hline $\mathrm{C} 1$ & - & 0.90 & 0.50 & 0.90 & $\mathrm{C} 1$ & - & 0.70 & 0.70 & 0.90 \\
\hline $\mathrm{C} 2$ & 0.90 & - & 0.70 & 0.70 & $C 2$ & 1.00 & - & 0.70 & 0.90 \\
\hline C3 & 0.70 & 0.50 & - & 0.50 & C3 & 0.70 & 0.30 & - & 0.50 \\
\hline C4 & 0.70 & 0.70 & 0.90 & - & $\mathrm{C} 4$ & 0.70 & 0.50 & 0.70 & - \\
\hline \multicolumn{5}{|c|}{ Decision maker 3} & \multicolumn{5}{|c|}{ Decision maker 4} \\
\hline P3 & $\mathrm{C} 1$ & $\mathrm{C2}$ & $\mathrm{C3}$ & $\mathrm{C} 4$ & $\mathrm{P4}$ & C1 & $\mathrm{C2}$ & $\mathrm{C3}$ & $\mathrm{C} 4$ \\
\hline $\mathrm{C} 1$ & - & 0.70 & 0.50 & 0.30 & $\mathrm{C} 1$ & - & 0.90 & 0.70 & 0.50 \\
\hline $\mathrm{C} 2$ & 0.70 & - & 0.70 & 0.70 & $\mathrm{C} 2$ & 1.00 & - & 0.70 & 0.90 \\
\hline C3 & 0.70 & 0.70 & - & 0.70 & $\mathrm{C} 3$ & 0.90 & 0.70 & - & 0.70 \\
\hline $\mathrm{C} 4$ & 0.50 & 0.90 & 0.70 & - & C4 & 0.70 & 0.70 & 0.70 & - \\
\hline
\end{tabular}

Table 16 Consensus-based Pythagorean fuzzy decision matrix for the equity-based crowdfunding alternative

\begin{tabular}{|c|c|c|c|c|c|c|c|c|c|}
\hline \multicolumn{5}{|c|}{ Decision maker 1} & \multicolumn{5}{|c|}{ Decision Maker 2} \\
\hline $\mathrm{P}^{1}$ & $\mathrm{C1}$ & $\mathrm{C2}$ & $\mathrm{C3}$ & $\mathrm{C4}$ & $\overline{P^{2}}$ & C1 & $\mathrm{C2}$ & C3 & C4 \\
\hline $\mathrm{C} 1$ & - & {$[0.45,0.28]$} & {$[0.63,0.19]$} & {$[0.63,0.19]$} & $\mathrm{C} 1$ & - & {$[0.45,0.28]$} & {$[0.63,0.19]$} & {$[0.45,0.28]$} \\
\hline $\mathrm{C} 2$ & {$[0.63,0.19]$} & - & {$[0.45,0.28]$} & {$[0.45,0.28]$} & $\mathrm{C} 2$ & {$[0.63,0.19]$} & - & {$[0.63,0.19]$} & {$[0.63,0.19]$} \\
\hline C3 & {$[0.45,0.28]$} & {$[0.45,0.28]$} & - & {$[0.81,0.10]$} & $\mathrm{C} 3$ & {$[0.63,0.19]$} & {$[0.45,0.28]$} & - & {$[0.63,0.19]$} \\
\hline $\mathrm{C} 4$ & {$[0.81,0.10]$} & {$[0.45,0.28]$} & {$[0.63,0.19]$} & - & $\mathrm{C} 4$ & {$[0.63,0.19]$} & {$[0.45,0.28]$} & {$[0.63,0.19]$} & - \\
\hline \multicolumn{5}{|c|}{ Decision maker 3} & \multicolumn{5}{|c|}{ Decision maker 4} \\
\hline $\mathrm{P}^{3}$ & $\mathrm{C1}$ & $\mathrm{C2}$ & C3 & $\mathrm{C4}$ & $\overline{\mathrm{P}^{4}}$ & C1 & $\mathrm{C2}$ & $\mathrm{C3}$ & C4 \\
\hline $\mathrm{C} 1$ & - & {$[0.45,0.28]$} & {$[0.63,0.19]$} & {$[0.81,0.10]$} & $\mathrm{C} 1$ & - & {$[0.81,0.10]$} & {$[0.63,0.19]$} & {$[0.63,0.19]$} \\
\hline $\mathrm{C} 2$ & {$[0.63,0.19]$} & - & {$[0.45,0.28]$} & {$[0.45,0.28]$} & $\mathrm{C} 2$ & {$[0.63,0.19]$} & - & {$[0.45,0.28]$} & {$[0.90,0.05]$} \\
\hline C3 & {$[0.81,0.10]$} & {$[0.45,0.28]$} & - & {$[0.81,0.10]$} & $\mathrm{C} 3$ & {$[0.63,0.19]$} & {$[0.63,0.19]$} & - & {$[0.63,0.19]$} \\
\hline C4 & {$[0.45,0.28]$} & {$[0.45,0.28]$} & {$[0.63,0.19]$} & - & $\mathrm{C} 4$ & {$[0.45,0.28]$} & {$[0.81,0.10]$} & {$[0.45,0.28]$} & - \\
\hline
\end{tabular}

Table 17 Defuzzified relation matrix for the equity-based crowdfunding alternative

\begin{tabular}{lllll}
\hline Criteria & C1 & C2 & C3 & C4 \\
\hline C1 & 0.000 & 0.239 & 0.363 & 0.363 \\
C2 & 0.363 & 0.000 & 0.181 & 0.331 \\
C3 & 0.363 & 0.181 & 0.000 & 0.499 \\
C4 & 0.299 & 0.239 & 0.299 & 0.000 \\
\hline
\end{tabular}

\section{Measuring the service development paths of clean energy investment projects by the crowdfunding alternatives (phase 4)}

In the first step, the immediate predecessors of service development process activities are selected. The values of D-E illustrate the influencing degrees of criteria. Accordingly, the criteria with positive D-E values mean that they affect the following activities, 
Table 18 Normalized relation matrix for the equity-based crowdfunding alternative

\begin{tabular}{lllll}
\hline Criteria & C1 & C2 & C3 & C4 \\
\hline C1 & 0.000 & 0.229 & 0.348 & 0.348 \\
C2 & 0.348 & 0.000 & 0.174 & 0.317 \\
C3 & 0.348 & 0.174 & 0.000 & 0.478 \\
C4 & 0.287 & 0.229 & 0.287 & 0.000 \\
\hline
\end{tabular}

Table 19 Total relation matrix for the equity-based crowdfunding alternative

\begin{tabular}{lllll}
\hline Criteria & C1 & C2 & C3 & C4 \\
\hline C1 & 2.030 & 1.642 & 2.076 & 2.567 \\
C2 & 2.118 & 1.338 & 1.816 & 2.347 \\
C3 & 2.399 & 1.691 & 1.923 & 2.768 \\
C4 & 2.042 & 1.491 & 1.850 & 2.068 \\
\hline
\end{tabular}

Table 20 The values of D, E, and weights of criteria for the crowdfunding alternatives

\begin{tabular}{llllrc}
\hline Criteria & D & E & D $+\mathbf{E}$ & D - E & Weights \\
\hline Equity-based & & & & & \\
Design (criterion 1) & 8.314 & 8.589 & 16.903 & -0.275 & 0.263 \\
Analysis (criterion 2) & 7.619 & 6.162 & 13.781 & 1.457 & 0.214 \\
Development (criterion 3) & 8.781 & 7.664 & 16.445 & 1.116 & 0.256 \\
Full launch (criterion 4) & 7.451 & 9.750 & 17.201 & -2.299 & 0.267 \\
Reward-based & & & & & \\
Design (criterion 1) & 4.551 & 4.186 & 8.737 & 0.365 & 0.240 \\
Analysis (criterion 2) & 5.255 & 4.312 & 9.566 & 0.943 & 0.262 \\
Development (criterion 3) & 4.650 & 4.163 & 8.813 & 0.486 & 0.242 \\
Full launch (criterion 4) & 3.781 & 5.575 & 9.357 & -1.794 & 0.257 \\
Debt-based & & & & & \\
Design (criterion 1) & 6.223 & 5.709 & 11.933 & 0.514 & 0.244 \\
Analysis (criterion 2) & 5.175 & 5.633 & 10.808 & -0.457 & 0.221 \\
Development (criterion 3) & 6.151 & 6.412 & 12.563 & -0.261 & 0.257 \\
Full launch (criterion 4) & 6.883 & 6.678 & 13.561 & 0.205 & 0.278 \\
Royalty-based & & & & & \\
Design (criterion 1) & 3.546 & 4.930 & 8.477 & -1.384 & 0.263 \\
Analysis (criterion 2) & 3.886 & 3.860 & 7.746 & 0.026 & 0.240 \\
Development (criterion 3) & 4.766 & 3.574 & 8.341 & 1.192 & 0.259 \\
Full launch (criterion 4) & 3.920 & 3.754 & 7.674 & 0.165 & 0.238 \\
Donation-based & & & & & \\
Design (criterion 1) & 2.474 & 3.174 & 5.648 & -0.701 & 0.265 \\
Analysis (criterion 2) & 3.437 & 2.454 & 5.891 & 0.983 & 0.277 \\
Development (criterion 3) & 2.097 & 2.493 & 4.590 & -0.396 & 0.216 \\
Full launch (criterion 4) & 2.637 & 2.523 & 5.160 & 0.114 & 0.242 \\
\hline & & & & & \\
\hline
\end{tabular}

making them immediate predecessors of the project. However, the criteria with negative D-E values are influenced by the other criteria, and they are not immediate predecessors of other activities. Additionally, it is assumed that the first activity is always 
the immediate predecessor of the second activity even if it has a negative $\mathrm{D}-\mathrm{E}$ value. The D-E value of the last activity is not used because there is not the following activity. Accordingly, the immediate predecessors are illustrated by the crowdfunding alternatives in Table 21.

In the following step, the project capacities by the paths for the alternatives are determined. By considering the immediate predecessors of the activities, the paths are determined and the weights of the criteria in the path are calculated to determine project capacities by the service development paths in clean energy investment projects. The results are presented in Table 22.

Then, the decision matrix for the alternatives is constructed, where the values of $\mathrm{D}+\mathrm{E}$ are considered as the importance degrees for the crowdfunding alternatives in terms of the service development criteria and activities, which is used for constructing the decision matrix. TOPSIS is used to rank the performance of the crowdfunding alternatives by considering the service development criteria. The normalized values of the decision matrix are shown in Table 23.

Following, the weighted decision matrix is calculated, and the average values of the criteria weights are used for constructing the weighted decision matrix. The results are given in Table 24.

Table 21 Immediate predecessors of the service development process by the crowdfunding alternatives

\begin{tabular}{lcl}
\hline Criteria/process & D - E & Immediate predecessors \\
\hline Equity-based & & \\
Design (criterion 1)/activity 1 & -0.275 & - \\
Analysis (criterion 2)/activity 2 & 1.457 & Activity 1 \\
Development (criterion 3)/activity 3 & 1.116 & Activity 2 \\
Full launch (criterion 4)/activity 4 & -2.299 & Activity 2, Activity 3 \\
Reward-based & & \\
Design (criterion 1)/Activity 1 & 0.365 & - \\
Analysis (criterion 2)/activity 2 & 0.943 & Activity 1 \\
Development (criterion 3)/activity 3 & 0.486 & Activity 1, Activity 2 \\
Full launch (criterion 4)/activity 4 & -1.794 & Activity 1, Activity 2, Activity 3 \\
Debt-based & & - \\
Design (criterion 1)/activity 1 & 0.514 & Activity 1 \\
Analysis (criterion 2)/activity 2 & -0.457 & Activity 1 \\
Development (criterion 3)/Activity 3 & -0.261 & Activity 1 \\
Full launch (criterion 4)/activity 4 & 0.205 & \\
Royalty-based & & - \\
Design (criterion 1)/activity 1 & -1.384 & Activity 1 \\
Analysis (criterion 2)/activity 2 & 0.026 & Activity 1, Activity 2 \\
Development (criterion 3)/activity 3 & 1.192 & Activity 1, Activity 2, Activity 3 \\
Full launch (criterion 4)/Activity 4 & 0.165 & \\
Donation-based & -0.701 & \\
Design (criterion 1)/activity 1 & 0.983 & \\
Analysis (criterion 2)/activity 2 & 0.114 & \\
Development (criterion 3)/activity 3 & & \\
Full launch (criterion 4)/activity 4 & & \\
\hline & &
\end{tabular}


Table 22 The project paths and capacities for the service development in clean energy investment projects by the crowdfunding alternatives

\begin{tabular}{lll}
\hline Paths & Activities & $\begin{array}{c}\text { Project } \\
\text { capacities }\end{array}$ \\
\hline $\begin{array}{l}\text { Equity-based } \\
\text { Path 1 }\end{array}$ & 1.000 \\
Path 2 & Activity 1, Activity 2, Activity 3, Activity 4 & 0.744 \\
Reward-based & Activity 1, Activity 2, Activity 4 & \\
Path 1 & Activity 1, Activity 3, Activity 4 & 0.738 \\
Path 2 & Activity 1, Activity 2, Activity 3, Activity 4 & 1.000 \\
Path 3 & Activity 1, Activity 2, Activity 4 & 0.758 \\
Path 4 & Activity 1, Activity 4 & 0.496 \\
Debt-based & & 1.000 \\
Path 1 & Activity 1, Activity 4 & 0.760 \\
Royalty-based & & 1.000 \\
Path 1 & Activity 1, Activity 3, Activity 4 \\
Path 2 & Activity 1, Activity 2, Activity 3, Activity 4 & 0.741 \\
Path 3 & Activity 1, Activity 2, Activity 4 & 0.501 \\
Path 4 & Activity 1, Activity 4 & \\
Donation-based & & 0.508 \\
Path 1 & Activity 1, Activity 4 & 0.784 \\
Path 2 & Activity 1, Activity 2, Activity 4 & \\
\hline
\end{tabular}

Table 23 Normalized decision matrix

\begin{tabular}{lllll}
\hline Alternatives & $\begin{array}{l}\text { Design } \\
\text { (criterion 1) }\end{array}$ & $\begin{array}{l}\text { Analysis } \\
\text { (criterion 2) }\end{array}$ & $\begin{array}{l}\text { Development } \\
\text { (criterion 3) }\end{array}$ & $\begin{array}{l}\text { Full launch } \\
\text { (criterion 4) }\end{array}$ \\
\hline Equity-based (alternative 1) & 0.685 & 0.621 & 0.673 & 0.673 \\
Reward-based (alternative 2) & 0.354 & 0.431 & 0.361 & 0.366 \\
Debt-based (alternative 3) & 0.484 & 0.487 & 0.514 & 0.531 \\
Royalty-based (alternative 4) & 0.344 & 0.349 & 0.341 & 0.300 \\
Donation-based (alternative 5) & 0.229 & 0.265 & 0.188 & 0.202 \\
\hline
\end{tabular}

Table 24 Weighted decision matrix

\begin{tabular}{lllll}
\hline Alternatives & $\begin{array}{l}\text { Design } \\
\text { (criterion 1) }\end{array}$ & $\begin{array}{l}\text { Analysis } \\
\text { (criterion 2) }\end{array}$ & $\begin{array}{l}\text { Development } \\
\text { (criterion 3) }\end{array}$ & $\begin{array}{l}\text { Full launch } \\
\text { (criterion 4) }\end{array}$ \\
\hline Equity-based (alternative 1) & 0.175 & 0.151 & 0.165 & 0.173 \\
Reward-based (alternative 2) & 0.090 & 0.105 & 0.089 & 0.094 \\
Debt-based (alternative 3) & 0.123 & 0.118 & 0.126 & 0.136 \\
Royalty-based (alternative 4) & 0.088 & 0.085 & 0.084 & 0.077 \\
Donation-based (alternative 5) & 0.058 & 0.064 & 0.046 & 0.052 \\
\hline
\end{tabular}

Finally, the alternatives are ranked (Table 25).

Table 25 outlines that equity-based crowdfunding is the most appropriate alternative for the effectiveness of clean energy investment projects, and debt-based 
Table 25 Ranking the crowdfunding alternatives for the service development process of clean energy investment projects

\begin{tabular}{lllll}
\hline Alternatives & D+ & D- & RCi & Ranking \\
\hline Equity-based (alternative 1) & 0.000 & 0.223 & 1.000 & 1 \\
Reward-based (alternative 2) & 0.146 & 0.079 & 0.350 & 3 \\
Debt-based (alternative 3) & 0.081 & 0.144 & 0.640 & 2 \\
Royalty-based (alternative 4) & 0.167 & 0.058 & 0.257 & 4 \\
Donation-based (alternative 5) & 0.223 & 0.000 & 0.000 & 5 \\
\hline
\end{tabular}

Table 26 Sensitivity Analysis with TOPSIS and VIKOR

\begin{tabular}{|c|c|c|c|c|c|c|c|c|}
\hline \multirow[t]{2}{*}{ Alternatives } & \multicolumn{4}{|l|}{ TOPSIS } & \multicolumn{4}{|l|}{ VIKOR } \\
\hline & Case 1 & Case 2 & Case 3 & $\overline{\text { Case } 4}$ & Case 1 & Case 2 & Case 3 & Case 4 \\
\hline Equity-based (alternative 1) & 1 & 1 & 1 & 1 & 1 & 1 & 1 & 1 \\
\hline Reward-based (alternative 2) & 3 & 3 & 4 & 4 & 4 & 3 & 3 & 3 \\
\hline Debt-based (alternative 3) & 2 & 2 & 2 & 2 & 2 & 2 & 2 & 2 \\
\hline Royalty-based (alternative 4) & 4 & 4 & 3 & 3 & 3 & 4 & 4 & 4 \\
\hline Donation-based (alternative 5) & 5 & 5 & 5 & 5 & 5 & 5 & 5 & 5 \\
\hline
\end{tabular}

crowdfunding is the second-best alternative. Reward, royalty, and donation-based alternatives have lower importance in comparison.

\section{Sensitivity analysis and comparative ranking results}

A comparative evaluation is performed using VIKOR to rank the alternatives. Sensitivity analysis is conducted by considering four cases. Table 26 provides the details of the sensitivity analysis results with the TOPSIS and VIKOR approaches.

Table 26 demonstrates that the ranking results are similar for TOPSIS and VIKOR, as are the analysis results of the four cases. This situation shows that the findings are coherent and reliable.

\section{Conclusion and discussion}

This study identified the appropriate crowdfunding alternatives for new service development process pathways of clean energy investment projects using a proposed four-stage novel model. First, the missing values of the relation matrices were completed with the help of the iteration technique. Second, the consensus-based fuzzy preferences for the criteria of the crowdfunding alternatives were identified. Third, the service development process of clean energy investment projects by the crowdfunding alternatives was evaluated with the Pythagorean fuzzy DEMATEL method. Fourth, the service development paths of clean energy investment projects by the crowdfunding alternatives were ranked. The Pythagorean fuzzy TOPSIS methodology was used, a comparative evaluation was performed with VIKOR methodology, and sensitivity analysis was conducted using four cases.

The findings demonstrate that the analysis results are coherent and reliable, concluding that the full launch is the most significant criterion for equity and debt-based 
crowdfunding alternatives. Moreover, the analysis weights reward and donation-based alternatives highest, whereas design is the most essential item regarding the royaltybased alternative. Additionally, the equity-based crowdfunding alternative is the most significant for the service development process of clean energy investment projects.

Clean energy investments have high initial costs, which makes investors anxious regarding clean energy projects. Hence, some energy investors prefer fossil fuels to manage the costs of the projects more effectively. Therefore, the high initial cost is a major obstacle to increasing the number of clean energy projects. Thus, it is vital to select the financing source of the projects correctly. The results of this study show that the most suitable alternative in this process is equity-based crowdfunding. Hence, the best practice is for a large number of investors to finance clean energy investment projects in return for equity. This method is advantageous. First, if the firm makes a profit, it can distribute dividends, and this does not create a fixed-cost burden for the company. If the company does not make a profit, it does not make payouts to investors. Second, since the equity does not have a specific maturity, it is possible for the clean energy firm to continuously provide a source of finance.

Previous studies have emphasized the importance of clean energy investments. Jaber et al. (2015), Zhang et al. (2016a, b), and Bean et al. (2017) stated that, in financing clean energy investments, the equity financing method is preferred compared to the debt financing method. Clean energy investments are long-term investments with high costs, which cause debt-increase financing and the burden of investors. Similarly, Kim and Park (2018), Tian (2018), and Kempa et al. (2021) identified that if the investments do not make enough profit, especially in the first periods, it is difficult for investors to repay the debt, which prevents the sustainable success of the project. Therefore, in clean energy investments, the repayment of the financing should be directly proportional to the profit received. Furthermore, He et al. (2019), Anton and Nucu (2020), and Rahim and Mohamad (2018) determined that financing for clean energy projects must be continuous. Hence, it is difficult to provide long-term financing for these projects through practices, such as donations. Relying solely on donations when financing these projects runs the risk of not finding additional resources while the project continues.

This study has several theoretical and practical implications. The proposed model constructed in this study offers theoretical advancement for researchers. The novel model was created to evaluate the crowdfunding alternatives regarding new service development process pathways of clean energy investment projects by considering the consensus-based group decision-making with incomplete preferences, Pythagorean fuzzy DEMATEL, and TOPSIS. Furthermore, by making a comparative evaluation and sensitivity analysis, this model is reliable and consistent. Therefore, researchers in multiple fields can utilize this complex model. Practically, the results of this study can guide investors and policymakers. To improve clean energy investments, governments should provide the necessary support to increase equity-based financing. For example, reducing legal procedures in this process will make it easier for investors. Additionally, for an equity-based financing system to develop, taxes on such investments can be reduced. Both suggestions will have positive contributions to increase clean energy investments.

The main contribution of this study is to identify appropriate crowdfunding-based funding alternatives for the improvement of the clean energy investments with a novel 
MCDM model by considering the group decision-making with consensus and Pythagorean fuzzy sets. However, the study has some limitations. A general examination of clean energy types was conducted. However, future studies should analyze this issue specifically for several types of clean energy. This study conducted an analysis only for the best financing alternative, which will guide investors and researchers. However, no sectoral application was made. Additionally, this study only aimed to identify the critical factors to increase clean energy investments. Future studies should consider a situation analysis for the sector to contribute significantly to the literature. Moreover, the consistency and coherency of the proposed model of this study are evaluated in the analysis process. Hence, this model can be considered for academicians in various fields.

\section{Acknowledgements}

This work is supported by the project of Sichuan county economic development research center of Sichuan provincial key research base of social sciences, "research on the coordination mechanism of county economic, ecological and social coupling development of giant panda national park" (xy2020034) and the social science special research project of Sichuan agricultural university "research on innovation of modern urban agricultural development mode" (035/ 03571600)

\section{Authors' contributions}

All the authors contributed equally to this work. All authors read and approved the final manuscript.

\section{Funding}

This work is supported by the project of Sichuan county economic development research center of Sichuan provincial key research base of social sciences, "research on the coordination mechanism of county economic, ecological and social coupling development of giant panda national park" (xy2020034) and the social science special research project of Sichuan agricultural university "research on innovation of modern urban agricultural development mode" (035/03571600).

\section{Availability of data and materials}

In this study, 4 different experts made evaluations about the criteria. These evaluations are considered as input data in the study. The data used to support the findings of this study are included within the article.

\section{Declarations}

Competing interests

The authors declare that they have no competing interests.

\section{Author details}

${ }^{1}$ College of Tourism, Sichuan Agricultural University, Chengdu 611830, China. ${ }^{2}$ College of Management, Sichuan Agricultural University, Chengdu 611830, China. ${ }^{3}$ School of Business, İstanbul Medipol University, Kavacık Mah. Ekinciler Cad. No: 19, Kavacık Kavşağı, 34810 Beykoz, Istanbul, Turkey.

Received: 4 February 2021 Accepted: 27 April 2021

Published online: 06 May 2021

\section{References}

Ahlers GK, Cumming D, Günther C, Schweizer D (2015) Signaling in equity crowdfunding. Entrep Theory Pract 39(4):955-980

Akram M, llyas F, Garg H (2020a) Multi-criteria group decision making based on ELECTRE I method in Pythagorean fuzzy information. Soft Comput 24(5):3425-3453

Akram M, Luqman A, Alcantud JCR (2020b) Risk evaluation in failure modes and effects analysis: hybrid TOPSIS and ELECTRE I solutions with Pythagorean fuzzy information. Neural Comput Appl 23:1-29

Akram M, Kahraman C, Zahid K (2021b) Group decision-making based on complex spherical fuzzy VIKOR approach. Knowl Based Syst 216:106793

Akram M, Ilyas F, Al-Kenani AN (2021a) Two-phase group decision-aiding system using ELECTRE III method in Pythagorean fuzzy environment. Arab J Sci Eng 46:1-18

Albino V, Ardito L, Dangelico RM, Petruzzelli AM (2014) Understanding the development trends of low-carbon energy technologies: a patent analysis. Appl Energy 135:836-854

Anton SG, Nucu AEA (2020) The effect of financial development on renewable energy consumption. A panel data approach. Renew Energy 147:330-338

Bakioglu G, Atahan AO (2021) AHP integrated TOPSIS and VIKOR methods with Pythagorean fuzzy sets to prioritize risks in self-driving vehicles. Appl Soft Comput 99:106948

Bashir MF, Jiang B, Komal B, Bashir MA, Farooq TH, Iqbal N, Bashir M (2020) Correlation between environmental pollution indicators and COVID-19 pandemic: a brief study in Californian context. Environ Res 187:109652 
Bean P, Blazquez J, Nezamuddin N (2017) Assessing the cost of renewable energy policy options: a Spanish wind case study. Renew Energy 103:180-186

Block JH, Groh A, Hornuf L, Vanacker T, Vismara S (2020) The entrepreneurial finance markets of the future: a comparison of crowdfunding and initial coin offerings. Small Bus Econ 7:1-18

Carter E, Yan L, Fu Y, Robinson B, Kelly F, Elliott P, Baumgartner J (2020) Household transitions to clean energy in a multiprovincial cohort study in China. Nat Sustain 3(1):42-50

Chen SM, Lin TE, Lee LW (2014) Group decision making using incomplete fuzzy preference relations based on the additive consistency and the order consistency. Inf Sci 259:1-15

Cheng F, Lin M, Yüksel S, Dincer H, Kalkavan H (2020) A hybrid hesitant 2-tuple IVSF decision making approach to analyze PERT-based critical paths of new service development process for renewable energy investment projects. IEEE Access 9:3947-3969

Cloke J, Mohr A, Brown E (2017) Imagining renewable energy: towards a social energy systems approach to community renewable energy projects in the Global South. Energy Res Soc Sci 31:263-272

Cocca S, Ganz W (2015) Requirements for developing green services. Serv Ind J 35(4):179-196

Delen D, Dorokhov O, Dorokhova L, Dinçer H, Yüksel S (2020) Balanced scorecard-based analysis of customer expectations for cosmetology services: a hybrid decision modeling approach. J Manag Anal 7(4):532-563

Dhiman HS, Deb D (2020) Fuzzy TOPSIS and fuzzy COPRAS based multi-criteria decision making for hybrid wind farms. Energy 202:117755

Di Pietro F, Grilli L, Masciarelli F (2020) Talking about a revolution? Costly and costless signals and the role of innovativeness in equity crowdfunding. J Small Bus Manag 32:1-32

Dimić V, Milošević M, Milošević D, Stević D (2018) Adjustable model of renewable energy projects for sustainable development: a case study of the Nišava district in Serbia. Sustainability 10(3):775

Dincer H, Yüksel S, Martinez L (2019) Balanced scorecard-based Analysis about European Energy Investment Policies: A hybrid hesitant fuzzy decision-making approach with Quality Function Deployment. Expert Syst Appl 115:152-171

Domigall Y, Albani A, Winter R (2014) Identification of customer preferences for new service development in the electricity domain. In: 2014 IEEE 16th conference on business informatics. IEEE, vol 1, pp 207-214

Dong Y, Zha Q, Zhang H, Kou G, Fujita H, Chiclana F, Herrera-Viedma E (2018) Consensus reaching in social network group decision making: research paradigms and challenges. Knowl Based Syst 162:3-13

Fei L, Deng Y (2020) Multi-criteria decision making in Pythagorean fuzzy environment. Appl Intell 50(2):537-561

Frydrych D, Bock AJ, Kinder T, Koeck B (2014) Exploring entrepreneurial legitimacy in reward-based crowdfunding. Ventur Cap 16(3):247-269

Gutiérrez-Urtiaga M, Sáez-Lacave MI (2018) The promise of reward crowdfunding. Corp Gov Int Rev 26(5):355-373

Han D, LiT, Feng S, Shi Z (2020) Application of threshold regression analysis to study the impact of clean energy development on China's carbon productivity. Int J Environ Res Public Health 17(3):1060

He L, Liu R, Zhong Z, Wang D, Xia Y (2019) Can green financial development promote renewable energy investment efficiency? A consideration of bank credit. Renew Energy 143:974-984

Hicks J, Ison N (2018) An exploration of the boundaries of'community'in community renewable energy projects: navigating between motivations and context. Energy Policy 113:523-534

Hörisch J (2019) Take the money and run? Implementation and disclosure of environmentally-oriented crowdfunding projects. J Clean Prod 223:127-135

Hörisch J, Tenner I (2020) How environmental and social orientations influence the funding success of investment-based crowdfunding: the mediating role of the number of funders and the average funding amount. Technol Forecast Soc Change 161:120311

Hornuf L, Neuenkirch M (2017) Pricing shares in equity crowdfunding. Small Bus Econ 48(4):795-811

Hornuf L, Schwienbacher A (2017) Should securities regulation promote equity crowdfunding? Small Bus Econ 49(3):579-593

Hosseini SM, Saifoddin A, Shirmohammadi R, Aslani A (2019) Forecasting of $\mathrm{CO}_{2}$ emissions in Iran based on time series and regression analysis. Energy Rep 5:619-631

Huang Y, Yang L, Gao C, Jiang Y, Dong Y (2019) A novel prediction approach for short-term renewable energy consumption in China based on improved Gaussian Process Regression. Energies 12(21):4181

Jaber JO, Elkarmi F, Alasis E, Kostas A (2015) Employment of renewable energy in Jordan: current status, SWOT and problem analysis. Renew Sustain Energy Rev 49:490-499

Jumin E, Basaruddin FB, Yusoff YBM, Latif SD, Ahmed AN (2021) Solar radiation prediction using boosted decision tree regression model: a case study in Malaysia. Environ Sci Pollut Res 25:1-13

Kempa K, Moslener U, Schenker O (2021) The cost of debt of renewable and non-renewable energy firms. Nat Energy 95:1-8

Kim J, Park K (2018) Effect of the clean development mechanism on the deployment of renewable energy: less developed vs. well-developed financial markets. Energy Econ 75:1-13

Kraus S, Richter C, Brem A, Cheng CF, Chang ML (2016) Strategies for reward-based crowdfunding campaigns. J Innov Knowl 1(1):13-23

Labella Á, Liu Y, Rodríguez RM, Martínez L (2018) Analyzing the performance of classical consensus models in large scale group decision making: a comparative study. Appl Soft Comput 67:677-690

Lacerda JS, van den Bergh JC (2020) Effectiveness of an 'open innovation' approach in renewable energy: Empirical evidence from a survey on solar and wind power. Renew Sustain Energy Rev 118:109505

Lam PT, Law AO (2018) Financing for renewable energy projects: a decision guide by developmental stages with case studies. Renew Sustain Energy Rev 90:937-944

Langley P, Lewis S, McFarlane C, Painter J, Vradis A (2020) Crowdfunding cities: social entrepreneurship, speculation and solidarity in Berlin. Geoforum 115:11-20

Li G, Kou G, Peng Y (2016) A group decision making model for integrating heterogeneous information. IEEE Trans Syst Man Cybern Syst 48(6):982-992 
Li X, Zhu S, Yüksel S, Dinçer H, Ubay GG (2020) Kano-based mapping of innovation strategies for renewable energy alternatives using hybrid interval type-2 fuzzy decision-making approach. Energy 211:118679

Li G, Kou G, Peng Y (2021) Heterogeneous large-scale group decision-making using fuzzy cluster analysis and its application to emergency decision. IEEE Trans Syst Man Cybern Syst 29:1-14

Lin C, Kou G, Peng Y, Alsaadi FE (2020) Aggregation of the nearest consistency matrices with the acceptable consensus in AHP-GDM. Ann Oper Res 64:1-17

Liu H, Ma Y, Jiang L (2019) Managing incomplete preferences and consistency improvement in hesitant fuzzy linguistic preference relations with applications in group decision making. Inf Fusion 51:19-29

Lowitzsch J, Hoicka CE, Van Tulder FJ (2020) Renewable energy communities under the 2019 European Clean Energy Package-Governance model for the energy clusters of the future? Renew Sustain Energy Rev 122:109489

Lu Y, Chang R, Lim S (2018) Crowdfunding for solar photovoltaics development: a review and forecast. Renew Sustain Energy Rev 93:439-450

Lukkarinen A, Teich JE, Wallenius H, Wallenius J (2016) Success drivers of online equity crowdfunding campaigns. Decis Support Syst 87:26-38

Luqman A, Akram M, Alcantud JCR (2021) Digraph and matrix approach for risk evaluations under Pythagorean fuzzy information. Expert Syst Appl 170:114518

Ma X, Akram M, Zahid K, Alcantud JCR (2020) Group decision-making framework using complex Pythagorean fuzzy information. Neural Comput Appl 161:1-21

Mangla SK, Luthra S, Jakhar S, Gandhi S, Muduli K, Kumar A (2020) A step to clean energy—sustainability in energy system management in an emerging economy context. J Clean Prod 242:118462

Maqbool R (2018) Efficiency and effectiveness of factors affecting renewable energy projects; an empirical perspective. Energy 158:944-956

Martinez N, Komendantova N (2020) The effectiveness of the social impact assessment (SIA) in energy transition management: Stakeholders' insights from renewable energy projects in Mexico. Energy Policy 145:111744

Mirzania P, Ford A, Andrews D, Ofori G, Maidment G (2019) The impact of policy changes: the opportunities of Community Renewable Energy projects in the UK and the barriers they face. Energy Policy 129:1282-1296

Mochkabadi K, Volkmann CK (2020) Equity crowdfunding: a systematic review of the literature. Small Bus Econ 54(1):75-118

Montgomery N, Squires G, Syed I (2018) Disruptive potential of real estate crowdfunding in the real estate project finance industry. Prop Manag

Peng X, Yuan H, Yang Y (2017) Pythagorean fuzzy information measures and their applications. Int J Intell Syst 32(10):991-1029

Petruzzelli AM, Natalicchio A, Panniello U, Roma P (2019) Understanding the crowdfunding phenomenon and its implications for sustainability. Technol Forecast Soc Chang 141:138-148

Qiu D, Dinçer H, Yüksel S, Ubay GG (2020) Multi-faceted analysis of systematic risk-based wind energy investment decisions in E7 economies using modified hybrid modeling with IT2 fuzzy sets. Energies 13(6):1423

Rahim SRM, Mohamad ZZ (2018) Green Sukuk for financing renewable energy projects. TUJISE 5(2):129

Rani P, Mishra AR, Mardani A, Cavallaro F, Alrasheedi M, Alrashidi A (2020) A novel approach to extended fuzzy TOPSIS based on new divergence measures for renewable energy sources selection. J Clean Prod 257:120352

Rathore R, Thakkar JJ, Jha JK (2020) Evaluation of risks in foodgrains supply chain using failure mode effect analysis and fuzzy VIKOR. Int I Qual Reliab Manag

Ratner SV, Nizhegorodtsev RM (2017) Analysis of renewable energy projects'implementation in Russia. Therm Eng 64(6):429-436

Roma P, Petruzzelli AM, Perrone G (2017) From the crowd to the market: The role of reward-based crowdfunding performance in attracting professional investors. Res Policy 46(9):1606-1628

Rossi A, Vismara S (2018) What do crowdfunding platforms do? A comparison between investment-based platforms in Europe. Eurasian Bus Rev 8(1):93-118

Salido-Andres N, Rey-Garcia M, Alvarez-Gonzalez LI, Vazquez-Casielles R (2020) Mapping the field of donation-based crowdfunding for charitable causes: systematic review and conceptual framework. VOLUNTAS Int J Volunt Nonprofit Organ 96:1-15

Salimi AH, Noori A, Bonakdari H, Masoompour Samakosh J, Sharifi E, Hassanvand M, Agharazi M (2020) Exploring the role of advertising types on improving the water consumption behavior: an application of integrated fuzzy AHP and fuzzy VIKOR method. Sustainability 12(3):1232

Seetharaman A, Sandanaraj LL, Moorthy MK, Saravanan AS (2016) Enterprise framework for renewable energy. Renew Sustain Energy Rev 54:1368-1381

Shankar AV, Quinn AK, Dickinson KL, Williams KN, Masera O, Charron D, Rosenthal JP (2020) Everybody stacks: Lessons from household energy case studies to inform design principles for clean energy transitions. Energy Policy 141:111468

Sharaf IM (2020) Supplier selection using a flexible interval-valued fuzzy VIKOR. Granul Comput 5(4):485-501

Shi X, Liu X, Yao L (2016) Assessment of instruments in facilitating investment in off-grid renewable energy projects. Energy Policy 95:437-446

Terrapon-Pfaff J, Dienst C, König J, Ortiz W (2014) A cross-sectional review: impacts and sustainability of small-scale renewable energy projects in developing countries. Renew Sustain Energy Rev 40:1-10

Tian H (2018) Role of capital market to accelerate the transition to low-carbon energy system. In: Financing for lowcarbon energy transition. Springer, Singapore, pp 211-238

Vismara S (2016) Equity retention and social network theory in equity crowdfunding. Small Bus Econ 46(4):579-590

Vrontis D, Christofi M, Battisti E, Graziano EA (2020) Intellectual capital, knowledge sharing and equity crowdfunding. J Intell Cap

Vulkan N, Åstebro T, Sierra MF (2016) Equity crowdfunding: A new phenomena. J Bus Ventur Insights 5:37-49

Walthoff-Borm X, Schwienbacher A, Vanacker T (2018) Equity crowdfunding: first resort or last resort? J Bus Ventur 33(4):513-533 
Wang S, Liu Q, Yuksel S, Dincer H (2019) Hesitant linguistic term sets-based hybrid analysis for renewable energy investments. IEEE Access 7:114223-114235

Wang S, Ha J, Kalkavan H, Yüksel S, Dinçer H (2020) IT2-based hybrid approach for sustainable economic equality: S case of e7 economies. SAGE Open 10(2):2158244020924434

Wang H, Kou G, Peng Y (2021) An iterative algorithm to derive priority from large-scale sparse pairwise comparison matrix. IEEE Trans Syst Man Cybern Syst

Wu J, Chiclana F (2014) A social network analysis trust-consensus based approach to group decision-making problems with interval-valued fuzzy reciprocal preference relations. Knowl-Based Syst 59:97-107

Xie Y, Peng Y, Yüksel S, Dınçer H, Uluer GS, Çağlayan Ç, Li Y (2020) Consensus-based public acceptance and mapping of nuclear energy investments using spherical and pythagorean fuzzy group decision making approaches. IEEE Access 8:206248-206263

Yang XJ, Hu H, Tan T, Li J (2016) China's renewable energy goals by 2050. Environ Dev 20:83-90

Yu D, Kou G, Xu Z, Shi S (2021) Analysis of collaboration evolution in AHP research: 1982-2018. Int J Inf Technol Decis Mak IJTTDM 20(01):7-36

Yuan J, Zhang ZM, Yüksel S, Dinçer H (2020) Evaluating recognitive balanced scorecard-based quality improvement strategies of energy investments with the integrated hesitant 2-tuple interval-valued Pythagorean fuzzy decisionmaking approach to QFD. IEEE Access 8:171112-171128

Yüksel S, Dinçer H, Meral Y (2019) Financial analysis of international energy trade: a strategic outlook for EU-15. Energies 12(3):431

Zhang L, Lu W, Liu X, Pedrycz W, Zhong C (2016b) Fuzzy c-means clustering of incomplete data based on probabilistic information granules of missing values. Knowl Based Syst 99:51-70

Zhang D, Cao H, Zou P (2016a) Exuberance in China's renewable energy investment: rationality, capital structure and implications with firm level evidence. Energy Policy 95:468-478

Zhang Y, Tan CD, Sun J, Yang Z (2020) Why do people patronize donation-based crowdfunding platforms? An activity perspective of critical success factors. Comput Hum Behav 112:106470

Zhang J, Kou G, Peng Y, Zhang Y (2021) Estimating priorities from relative deviations in pairwise comparison matrices. Inf Sci 552:310-327

Zhou P, Zhou P, Yüksel S, Dinçer H, Uluer GS (2020) Balanced scorecard-based evaluation of sustainable energy investment projects with it2 fuzzy hybrid decision making approach. Energies 13(1):82

Ziemba P, Becker A, Becker J (2020) A consensus measure of expert judgment in the fuzzy TOPSIS method. Symmetry 12(2):204

\section{Publisher's Note}

Springer Nature remains neutral with regard to jurisdictional claims in published maps and institutional affiliations.

\section{Submit your manuscript to a SpringerOpen ${ }^{\odot}$ journal and benefit from:}

- Convenient online submission

- Rigorous peer review

- Open access: articles freely available online

- High visibility within the field

Retaining the copyright to your article

Submit your next manuscript at $\boldsymbol{\Delta}$ springeropen.com 